FEDERAL RESERVE BANK of ST. LOUIS

\section{RESEARCH DIVISION} Working Paper Series

\section{The Great Housing Boom of China}

\author{
Kaiji Chen \\ and \\ Yi Wen
}

Working Paper 2014-022C

https://doi.org/10.20955/wp.2014.022

June 2016

The views expressed are those of the individual authors and do not necessarily reflect official positions of the Federal Reserve Bank of St. Louis, the Federal Reserve System, or the Board of Governors.

Federal Reserve Bank of St. Louis Working Papers are preliminary materials circulated to stimulate discussion and critical comment. References in publications to Federal Reserve Bank of St. Louis Working Papers (other than an acknowledgment that the writer has had access to unpublished material) should be cleared with the author or authors. 


\title{
The Great Housing Boom of China
}

\author{
By KaIJI CHEN AND Yi WeN*
}

\begin{abstract}
China's housing prices have been growing nearly twice as fast as national income over the past decade, despite a high vacancy rate and a high rate of return to capital. This paper interprets China's housing boom as a rational bubble emerging naturally from its economic transition. The bubble arises because high capital returns driven by resource reallocation are not sustainable in the long run. Rational expectations of a strong future demand for alternative stores of value can thus induce currently productive agents to speculate in the housing market. Our model can quantitatively account for China's paradoxical housing boom.
\end{abstract}

Housing prices in China have experienced rapid and prolonged growth in the recent decade, rising nearly twice as fast as people's disposable income. Data for thirty-five major Chinese cities show that average real housing prices have grown at an annual rate of around 17 percent over the past decade, much higher than the average income growth rate of 11 percent across the thirty-five cities and the nation's 10 percent average gross domestic product (GDP) growth in the same period. Closely associated with the housing boom is the growing vacancy rate across Chinese cities, which reached a national average of 22.4 percent in 2013. Yet during the same period, China has also enjoyed a very high rate of return to capital. For example, between 1998 and 2012, China's real rate of return to capital (net of depreciation) was constantly around 20 percent or above.

The combination of these features-namely, (i) real housing prices outpacing income for a decade; (ii) a high vacancy rate, and (iii) a high rate of return to capital - is puzzling. A standard neoclassical model, even with an inelastic housing supply, predicts that housing prices would grow at most as fast as aggregate income; thus this type of models can hardly explain China's fast housing price growth and its high national vacancy rate. Alternatively, although the classical Samuelson-Tirole bubble model may explain the high vacancy rate in China, it requires the critical assumption that the rate of return to capital be so low that holding an intrinsically valueless bubble asset would be rational.

\footnotetext{
* Chen: Economics Department, Emory University, 1602 Fishburne Drive, Atlanta, GA 30322 (email: kaiji.chen@emory.edu), and the Research Department of the Federal Reserve Bank of Atlanta. Wen: Research Division, Federal Reserve Bank of St. Louis, P.O. Box 422, St. Louis, MO, 63166 (email: yi.wen@ stls.frb.org), and School of Economics and Management, Tsinghua University. We thank three anonymous referees for their very helpful comments and suggestions; Xiangyu Gong, Xin Wang, and Tong Xu for capable research assistance; Jing Wu for sharing data on China's housing prices; and Suqin Ge and Dennis Tao Yang for sharing data on China's real wage rate. We thank Toni Braun, Satyajit Chatterjee, YiLi Chien, Carlos Garriga, Lee Ohanian, B. Ravikumar, Manuel Santos, Zheng Song, Kjetil Storesletten, Gian Luca Violante, Yikai Wang, Tao Zha, and participants of the Brown Bag Seminar at the Federal Reserve Bank of St. Louis; 2013 Tsinghua Macro Workshop; 2013 Shanghai Macro Workshop; 2014 Spring Housing-Urban-Labor-Macro (HULM) conference; and 2014 Northwestern-SAIF Conference in Macroeconomic Policies and Business Cycles for helpful comments. The views expressed in this paper are those of the authors and should not be interpreted as reflecting the views of the Board of Governors of the Federal Reserve System or the regional Reserve Banks.
} 
But such an assumption is at odds with the prolonged high rate of return to capital in China.

In this paper, we propose a theory to explain the paradoxical housing boom in China. The key ingredient in our model is a transition stage featuring massive labor reallocation (after economic reform) from a conventional less productive sector to an emerging sector consisting of productive but financially constrained entrepreneurs. The rate of return to capital in the emerging sector remains persistently high during the transition stage because of the large pool of "surplus" labor gradually unleashed from the traditional sector. However, such high capital returns-driven mainly by resource reallocation-are clearly unsustainable in the long run. Thus, rational expectations of a significantly lower rate of return to capital in the remote future can induce current generations of entrepreneurs to seek alternative stores of value for their rapidly growing wealth. In a financially underdeveloped economy with a limited supply of financial assets, housing becomes a natural investment option for currently productive entrepreneurs - they rationally anticipate a strong demand for such an asset by future generations. This sustains a self-fulfilling growing housing bubble, with growth rates significantly higher than the average disposable income during the transition despite very high returns to capital.

We show that such a model, calibrated to match China's major macroeconomic features, such as GDP growth and labor market dynamics, can quantitatively replicate China's housing price dynamics over the past decade fairly well and still be consistent with many other salient features of the Chinese economy. Our theory also predicts that such a fast-growing housing bubble will lose steam as the economy approaches the Lewis turning point with exhausted surplus labor in the rural areas. This prediction is consistent with the recent labor market and housing market data from China.

Our paper fits into the fast-growing literature on economic development and resource misallocation under financial frictions. ${ }^{1}$ While the bulk of the literature emphasizes the effects of resource reallocation on improving allocative efficiency and the associated saving-investment dynamics during the transition, we argue that such a transition may also be prone to asset bubbles, especially growing bubbles, even when the economy enjoys fast productivity growth and high returns to capital. This prediction is also supported by evidence from other emerging economies in Asia, such as Korea, Taiwan, and Vietnam, which experienced housing bubbles during their respective economic transition periods featuring labor reallocation from traditional less productive sectors to the emerging and more productive sectors.

Our model is based on that of Song, Storesletten, and Zilibotti (2011, "SSZ" hereafter). The SSZ model is attractive for our purposes because it can endogenously generate and quantitatively account for some important features of China's economic transition, such as a persistently high rate of return to capital in the emerging sector, which we argue are key to understanding China's prolonged paradoxical housing boom. Our contribution and value added is to show that such a development path can sustain growing bubbles-

\footnotetext{
${ }^{1}$ See, for example, Jeong and Townsend (2007); Restuccia and Rogerson (2008); Guner, Ventura, and Xu (2008); Song, Storesletten, and Zilibotti (2011); Buera, Kaboski, and Shin (2011); Buera and Shin (2013); Moll (2014); and Midrigan and $\mathrm{Xu}$ (2014).
} 
bubbles that grow much faster than aggregate income for a long period despite a persistently high rate of return to capital.

Our paper is one of the first to study growing bubbles, as opposed to static bubbles or bubbles that grow at or below the growth rate of the economy. ${ }^{2}$ In addition, our model sheds light on the economic and welfare implications of China's housing bubble: It can significantly prolong China's economic transition and reduce social welfare. Unlike many traditional bubble models where bubbles are welfare improving because of dynamic inefficiency, bubbles in our model can exist even when the economy is dynamically efficient, thanks to a disparity between social and private rates of return to capital. $^{3}$ Hence, by crowding out private capital formation and other productive activities, the growing bubble in our model crowds out productive investment, prolongs economic transition, and reduces average welfare.

Our paper also contributes to the emerging literature on China's high housing price puzzle. Most theoretical works in this area focus on why the housing price level is so high in China. ${ }^{4}$ In sharp contrast, our paper focuses on why housing prices in China have been able to grow much faster than the average disposable income over a prolonged period. ${ }^{5}$ By shifting the analysis from the level of housing prices to the growth rate of housing prices, our paper sheds light on China's housing price dynamics, as well as why such a growing housing bubble may create resource misallocation and prolong China's economic transition, which is an issue unaddressed in the literature.

The remainder of the paper is organized as follows: Section I presents some institutional background and stylized facts about China's housing market to frame the questions we raise and support the key assumptions in our theoretical model. Section II describes a simple two-period benchmark model to illustrate our essential explanations of the housing boom, as well as the model's qualitative implications. Section III extends the analysis to a multi-period model for calibration and quantitative analysis. Section IV concludes with remarks for further research. The online Appendix contains proof of all Propositions and Lemmas.

\footnotetext{
${ }^{2}$ For the rapidly developing literature on housing bubble, see Caballero and Krishnamurthy (2006); Kocherlakota (2009); Farhi and Tirole (2012); Giglio and Severo (2012); Martin and Ventura (2012); Ventura (2012); Burnside, Eichenbaum, and Rebelo (2013); Miao and Wang (2013); and Galí (2014) among many others.

${ }^{3}$ See also Farhi and Tirole (2012) for a similar result. In both that paper and ours, agency frictions drive a wedge between the social rate of returns to capital and the equilibrium rate of return. Accordingly, bubbles exist even in an environment with dynamic efficiency. However, the reason that bubbles may reduce welfare differs between our paper and theirs. In their paper, the presence of bubbles raises the equilibrium interest rate, which reduces the price of other external liquid assets.

${ }^{4}$ See, for example, Wei, Zhang, and Liu (2012).

${ }^{5}$ Using income growth as a benchmark for housing price growth implies that (i) disposable income serves as a demand-side factor on housing prices and (ii) housing supply is relatively inelastic with respect to housing prices. See Hurst (2015) for such a model. The relatively inelastic housing supply is consistent with the institutional features in China. Specifically, the supply of constructible land in China is monopolized by the local government, which is subject to land quotas to urbanize rural land. Moreover, housing units at different locations and even different floor levels are essentially heterogeneous goods. Such a feature limits the substitutability of housing across Chinese cities or even across different districts within a city. As a result, housing markets in China are highly localized, which further reduces the price elasticity of the housing supply. In fact, the housing price index we examine in this paper is constructed using the hedonic method, which has been controlled for changes in complex-level attributes over time, including distance to a city center, the floor area ratio, etc. Accordingly, changes in such housing prices are reasonably isolated from pure changes in the housing/land supply caused by suburbanization or higher floor-area ratios, as recently observed in China.
} 


\section{Stylized Facts}

\section{A. Housing Price Growth and the Vacancy Rate}

It is well-known that the official housing price indices published by the Chinese government suffer from many measurement problems and do not control for housing quality. Hence, they tend to underestimate the growing trend of China's housing prices. ${ }^{6}$ To correct such problems, Wu, Deng, and Liu (2014) use independently constructed housing price indices based on sales of newly built housing units in thirty-five major Chinese cities. These city-level series are then aggregated into a national indicator using a weighted-average formula, with the total transaction volume during 2006-2010 in each city as the weight. The resulting national housing price index shows a much faster growth rate than the official housing price index. For example, the national real housing price index increased 17 percent per year between 2006:Q1 and 2010:Q4. If we ignore the negative impact of the 2008 financial crisis, the average growth rate of housing prices was about 20 percent per year during this period (see Figure 1, solid line with circles).

[Insert Figure 1 here]

The increase in housing prices in China is also accompanied by rapidly rising land prices. Figure 1 (dashed line with stars) shows that nationwide real constant-quality land values have grown at an average rate of more than 16 percent per year between 2004:Q1 and 2013:Q2. In particular, between 2006:Q1 and 2010:Q4, a period for which housing price data is available, land prices grew at an average rate of 26 percent, much faster than the housing price growth during the same period. Accordingly, rising land values have constituted an important and increasing share in housing prices. For example, according to $\mathrm{Wu}$, Gyourko, and Deng (2012), in the city of Beijing, land values averaged 37 percent of housing prices before 2008 and rose above 60 percent after 2010 .

Such a growth pattern of housing prices is prevalent across almost all major cities in China. Figure 2 shows that most of the thirty-five major cities in China have experienced a significantly faster growth rate in housing prices than city-level aggregate disposable income, which takes into account population growth due to migration. For example, in large cities such as Shanghai and Beijing, the average real growth rate of housing prices during the same period is two to three times larger than the respective real growth rate of disposable income. The fact that house prices grew persistently faster than aggregate disposable income at both the national and city levels casts doubt on the conventional wisdom that China's housing price growth is driven mainly by the increased utilitarian demand for housing due to rural-to-urban migration or solely by the rapidly increasing purchasing power of Chinese citizens. ${ }^{7}$

\footnotetext{
${ }^{6}$ For example, the National Bureau of Statistics of China (NBSC) provides two major housing price indices. Based on these housing price indices, the average growth rate of housing prices in China is below the average growth rate of the economy. However, Wu, Deng, and Liu (2014) argue that these measures are severely biased downward because they fail to control both the complex-level quality changes (e.g., housing suburbanization) and unit-level quality changes (e.g., developer pricing strategies).

${ }^{7}$ See Garriga, Tang, and Wang (2014) for the migration view of China's housing price boom.
} 
[Insert Figure 2 here]

In a more recent empirical study, Fang et al. (2015) use an independent data source for 120 Chinese cities to document the patterns of housing price growth and local per capita aggregate income growth in the sample period 2003-2013. Among other things, they found that housing prices grew persistently faster than per capita disposable income or gross regional product in the first- and second-tier cities in China. ${ }^{8}$ Such evidence is consistent with that presented by Wu, Deng, and Liu (2014).

Along with the housing boom is the continuously rising and high housing vacancy rate. According to the China Household Finance Survey (2014, "CHFS" hereafter), in 2013 the average vacancy rates in the first-, second-, and third-tier cities in China were 21.2 percent, 21.8 percent, and 23.2 percent, respectively. ${ }^{9}$ Among different groups of households, 35.1 percent of entrepreneurial households own vacant houses. Furthermore, the proportion of households with vacant houses increases with household income. In the top decile income group, for example, 39.7 percent of households have vacant houses, which is about 22 percentage points higher than households in the lowest income quartile.

Housing prices growing faster than income implies a rapidly rising price-to-income ratio for average wage earners. Ge and Yang (2014) use data from the China Household Income Survey (2014) and find that the growth rate of real wages has been increasing since the economic reform in 1997. Between 1998 and 2007, average real wage growth reached 9.0 percent per year, almost as fast as real per capita GDP growth. However, housing prices have been growing much faster (nearly twice as fast-the gap between real housing price growth and real wage growth is more than 8 percentage points). ${ }^{10}$

\section{B. Returns to Capital and Resource Reallocation}

It is well documented that the average real rate of return to capital in China has remained around 20 percent over the past decade (see, for example, Bai, Hsieh, and Qian, 2006). We reconfirm this finding here by constructing the real rate of return to capital following the approach of Bai, Hsieh, and Qian (2006). ${ }^{11}$ Panel A of Figure 3 shows that the real rate of return to capital was on average 20 percent between 1998 and 2012. In particular, it increased steadily from 18 percent in 2001 to 26 percent before the start of financial crisis in 2008. Similarly, the measured after-tax real rate of return to capital (excluding urban housing) averaged about 18.2 percent between 1998 and 2012, approx-

\footnotetext{
${ }^{8}$ China's first-tier cities usually refer to Beijing, Shanghai, Guangzhou, and Shenzhen, which constitute "The Big 4." Second-tier cities include the provincial capital cities and other municipalities directly under the central government. Third-tier cities include all other cities.

${ }^{9}$ The definition of vacancy rate in CHFS is the same as the homeowner vacancy rate defined in the U.S. Census Bureau's Housing Vacancies and Homeownership Survey (see CHFS, 2014). Specifically, it is calculated as the proportion of the homeowner inventory that is vacant and for sale. Hence, the definition of vacant housing units does not include housing units that are newly built but not yet sold, or empty housing for parents and children, or for leisure.

${ }^{10}$ According to the data from the NBSC, the national average growth rate of real per capita disposable income between 1998 and 2012 was 9.3 percent per year.

${ }^{11}$ Specifically, we measure the capital-to-output ratio at market prices and include any expected change in the price of capital as part of its returns. Our computed series of the real rates of returns to capital between 1998 and 2005 are essentially the same as those of Bai, Hsieh, and Qian. (2006).
} 
imately the same as the estimated growth rate of the aggregate housing prices in real terms. $^{12}$

Underlying the enduring high rate of return to capital is the massive labor reallocation in China. Panel B of Figure 3 plots the evolution of the share of private employment in total employment. Following SSZ, we adopt two measures of the private employment share: (i) the share of domestic private enterprises (DPE) in total employment (which equals employment in DPE plus state-owned enterprises); and (ii) $(\mathrm{DPE}+\mathrm{FE}) /(\mathrm{DPE}+\mathrm{FE}+\mathrm{SOE}+\mathrm{COE})$, where $\mathrm{FE}$ is employment of foreign enterprises, $\mathrm{COE}$ is that of collectively-owned enterprises, and SOE is that of state-owned enterprises. For both measures, the private employment share increased steadily for most years during the 1998-2011 period and surpassed 60 percent in 2011.

[Insert Figure 3 here]

\section{Empirical Evidence Consistent with the "Marginal Investor" Hypothesis}

A crucial premise in our theoretical bubble model that explains the three stylized facts of China's housing boom is the marginal investor hypothesis - the fast growth rate of housing prices (despite high returns to capital and a high vacancy rate) is mainly driven by the speculative housing demand from agents (entrepreneurs) in the productive sector of the economy, who have access to high returns to capital. Hence, the higher the private rate of return to capital, the faster housing price growth outpaces aggregate income growth.

A stylized fact of China's housing boom is that owners or investors holding vacant housing units consist not only of middle-income and high-income households, but also entrepreneurs and firms, including the most productive and profitable firms. Standard economic theories would find this phenomenon puzzling - it is paradoxical that well-todo entrepreneurs and productive firms with high capital returns would engage in speculative housing (or real estate) investment. Furthermore, such theories would find it even more puzzling that private firm returns to capital across different cities are positively correlated with or predictive of these cities' housing price growth outpacing local aggregate income growth.

In what follows, we document precisely these stylized facts from three different perspectives. First, we use household-level evidence to show the predictive power of entrepreneurial status in the vacancy rate of a city's housing market. Second, we conduct cross-city panel regression analysis to show a strong empirical linkage between excess housing price growth-defined as the growth rate of housing prices minus the growth rate of aggregate disposable income - and the rate of return to capital facing private firms across different regions. Finally, we use firm-level data to reveal the extent of firm involvement in real estate investment and the linkage between their returns to capital and ownership structure.

\footnotetext{
${ }^{12}$ The measured after-tax returns to capital excluding urban housing are computed by excluding the urban residential capital stock from the measured capital stock and by excluding imputed rent (assumed by the NBSC to be 3 percent of the original value of the residential capital stock) and tax on output and enterprise income from the capital income.
} 
HouseHold Evidence. - As noted, China's average vacancy rate was at least as high as 22.4 percent across cities in 2011, implying that nearly a quarter of privately-owned housing units in China are unoccupied (by owners or renters). What explains such a high homeowner vacancy rate? The CHFS, which conducts a regression of housing vacancy status against an exhaustive list of both household-level and macro-level variables, shows that a homeowner's entrepreneurial status (i.e., whether the homeowner owns a private business) has strong predictive power on the vacancy status of housing units in all Chinese cities. In other words, entrepreneurs with access to alternative assets (capital) are more likely to own vacant housing units than other types of homeowners. This fact holds true even if the regressions control for household income, the education level of the household head, the household's attitude about risky investments, the housing price-torent ratio, the urbanization rate, and whether the household has unmarried male members (see Table 1 of CHFS, 2014). Note that entrepreneurs account for 17 percent of China's urban population and that, conditional on holding vacant housing units, 25 percent of homeowners are entrepreneurs.

CRoss-City Evidence. - In our model, the marginal investors in the housing market are the entrepreneurs who have access to high returns to capital and yet decide to also participate in the housing market. This implies that the rate of returns to capital facing the marginal investor will dictate the rate of return to housing investment in a self-fulfilling housing bubble equilibrium by the no-arbitrage condition.

The concept of the marginal investor in our model is borrowed from the asset pricing literature, where the rate of return to risky assets is determined by a marginal investor able to participate in such an asset market with no borrowing constrained. As far as we know, the best empirical approach to support the marginal investor theory in the asset pricing literature is to assess the predictive power of the investor's marginal value of wealth (proxied by their leverage position) on excess asset returns (see, for example, Adrian, Etula, and Muir, 2014). Here we follow a similar strategy by investigating the predictive power of private capital returns in different cities on excess housing price growth. Our empirical findings suggest that: (i) across major Chinese cities, the private rate of return to capital is a strong predictor of the city's excess housing price growth; and (ii) capital returns of private firms have larger and more significant predictive power on excess housing returns than do capital returns of SOEs.

Specifically, we measure returns to capital in a region as the ratio of total profit to the net value of fixed assets. We run a panel fixed-effect regression of excess housing price growth against returns to capital of different types of firms in thirty-five major cities in China between 2006 and 2010. Columns (1) and (2) of Table 1 suggest that returns to capital are highly significant predictors of excess housing returns regardless of firm type (ownership). Column (3) shows that when both SOE and privately-owned firms are included as independent variables, the returns to capital of private enterprises are more significant and stronger predictors of excess housing price growth than SOE. This evidence suggests that private enterprises are more likely than SOE to be marginal investors in the housing market. 
[Insert Table 1 here]

Firm Evidence. - Firm-level data show that a substantial fraction of non-real estate firms (including very productive ones) in China engage in real estate investment unrelated to their original business. This stylized fact indicates not only a close link between returns to capital and housing returns, but also a possible source of the crowding-out effect the housing bubble has on capital investment (as we show in the next section).

Here we use data on publicly listed firms, from the China Stock Market and Accounting Research (CSMAR) database, to check the extent non-real estate firms are involved in real estate investment and issues related to our marginal investor hypothesis. We restrict our sample to firms that have been traded for at least two years on the China A-share stock market over the period 2007-2013. ${ }^{13}$ We exclude firms in the real estate and construction sectors.

As shown in Table 2, about 45 percent of firms have such investment properties (purchased for rent and capital gain, instead of as a necessary input or production factor in their own business). ${ }^{14}$ The share averages about 15 percent of these firms' total physical assets and is stable over time.

\section{[Insert Table 2 here]}

We now examine the difference in returns to capital across firm ownership types for all firms investing in the housing market. Our empirical evidence shows that SOE on average have lower capital returns than private firms, whih is consistent with our model. Specifically, we regress capital returns against the degree of state ownership. We construct capital returns at the firm level using the ratio of operating profit to the one-period lag of property, plants, and equipment (PPE), which have been excluded from the value of investment property since 2007 . We adopt three different measures to gauge the degree of state ownership. The first is a direct measure of the state-owned stock share and the second and third measures pertain simply to state-ownership dummies. For the second measure, the state-ownership dummy takes a value of 1 if its state-owned stock share exceeds 50 percent. For the third, the dummy takes a value of 1 if the state-owned stock share exceeds 25 percent. To be consistent with our model's assumption, we also add a one-digit industry dummy. ${ }^{15}$ As Table 3 shows, for all three measures, the rate of return

\footnotetext{
${ }^{13}$ Since January 1, 2007, all listed firms in China have been required to disclose their real estate holdings for investment purposes, which includes any land and buildings held for rental income and/or for capital appreciation.

${ }^{14}$ As mentioned by $\mathrm{Li}$, Shao, and Tao (2015), prominent examples of non-real estate firms diversifying into real estate include Youngor (a leading garment company), Kweichow Moutai (a leading liquor company), and Suning (a leading electronics retailer).

${ }^{15}$ The empirical model is

$$
K P_{i t}=\text { cons }+\beta \times S_{i t}+\sum_{j \in J} \gamma_{j} \times I_{n d} d_{u} m_{i}^{j}+\varepsilon_{i t},
$$
}

where $K P$ denotes the capital returns, $S_{i t}$ is the measure of the degree of a firm's state ownership, and Ind_dum is the industry dummy. 
to capital is indeed negatively correlated with the degree of state ownership among the firms investing in real estate. ${ }^{16}$

[Insert Table 3 here]

To sum up, the empirical evidence presented in this section supports our marginal investor hypothesis: (i) entrepreneurs or productive firms are extensively involved in the housing market and are an important determinant of China's high vacancy rate; (ii) private capital returns are highly predictive of the excess housing price growth across major cities in China; and (iii) on average, the returns to capital of SOE (that invest in the housing market) are lower than those of private firms and less predictive of excess housing price growth across major cities, suggesting that private firms tend to be the marginal investors.

\section{Crowding-out Effects on Capital Investment}

Data from the China Statistical Yearbook (2012, "CSY" hereafter) show that total real estate investment as a share of GDP increased by more than threefold, from 4.2 percent in 1999 to 13.2 percent in 2011, with residential investment accounting for about 70 percent of the boom. The average nominal growth rate of residential investment was 25.5 percent per year, compared with 13.9 percent for nominal GDP. Accordingly, the share of residential investment in GDP rose fourfold from 2.4 percent in 1999 to 9.5 percent in 2011.

On the other hand, the rapidly growing housing bubble has shown a strong crowdingout effect on China's capital formation for both SOE and private firms. We measure this effect by estimating the correlation coefficients between real housing price growth (deflated by the consumer price index) and non-real estate investment growth (deflated by the producer price index). ${ }^{17}$ To remove seasonal effects, we use year-over-year growth rates at monthly frequency.

Table 4 shows that the growth of real estate investment is significantly and positively correlated with housing price growth, while non-real estate investment is significantly negatively correlated with housing price growth. More importantly, the results show that the current growth in housing prices is a strong predictor of a future decrease in nonreal estate investment growth, with the peak correlation between housing price growth and investment growth reached at a five-month lead. This crowding-out effect of housing price growth on non-housing investment is consistent with our model's predictions, ${ }^{18}$ and also supported by independent empirical studies. For example, Li, Shao, and Tao (2015) find that firms with real-estate investment property tend to under-invest by 10 percent in fixed capital formation compared with their industry benchmark. Wu, Gyourko, and

\footnotetext{
${ }^{16}$ This does not rule out the possibility that in some industries monopolized by SOE (e.g., petroleum), SOE investing in the property market can also enjoy very high revenue-based productivity.

${ }^{17}$ Due to data availability constraints, we are only able to decompose aggregate investment into real estate investment and the rest.

${ }^{18}$ A wide class of models (e.g., Kocherlakota, 2009, and Martin and Ventura, 2012) predicts that housing bubbles, by serving as collateral, crowd in (instead of crowding out) capital investment.
} 
Deng (2015) find that, for publicly-listed firms, real estate value has no impact on fixed capital investment via the collateral channel. Similarly, Chen, Liu, and Zhou (2013) provide empirical evidences that increases in real estate prices tend to crowd out firms' fixed capital formation in China.

[Insert Table 4 here]

\section{E. Other Facts Concerning the Model Assumptions}

Our model makes the following simplifying assumptions: both the land supply and the interest rate are fixed. In addition, our model focuses on housing price dynamics over the past decade, which correspond to a period of massive SOE privatization in China.

Land Supply. Land available for home construction in China is strictly controlled by the government. During 1997-2000, land available for new construction was limited to 20.4 million acres; during 2001-2010, it was limited to no more than 30.72 million acres. These restrictions on the size and new release of construction land were further strengthened by the National Land Use Plan 2006-2020, passed by the State Council of China in August 2008. According to this regulation, the total land available for construction in urban and rural areas is limited to 506.25 million acres by 2010 and 558.6 million acres by 2020 . The same plan requests that the amount of cultivated land in 2010 and 2020 be maintained at 1.818 billion acres and 1.805 billion acres, respectively, the so-called redline lower limit for the total amount of arable land. As shown in Figure 4, since 2003, the amount of arable land has more or less stabilized, implying a de facto fixed supply of land for home and real estate construction.

[Insert Figure 4 here]

Financial Underdevelopment. In our model, access to cheap credit allows SOE to survive despite much lower productivity than private firms. In China, the interest rate is controlled by the central bank to facilitate cheap credit to SOE. As shown in Figure 5 , China's interest rates are essentially flat with the deposit rate substantially below the lending rate.

\section{[Insert Figure 5 here]}

In addition, the availability of financial assets as vehicles of household savings is quite limited in China: Stock markets are poorly regulated and dominated by SOE, the national capital account is closed, and the exchange rate is fixed or tightly managed. Accordingly, household savings consist mainly of bank deposits, which are channeled through stateowned banks to the conventional sector occupied mainly by SOE. ${ }^{19}$ Through a system of strict capital controls, where the state directly manages the banking sector and financial

\footnotetext{
${ }^{19}$ The household savings rates in China averaged 25 percent between 1998 and 2009 (Curtis, Lugauer and Mark, 2015) and bank deposits were the major share of household financial assets (e.g., 75 percent in 2004-2005 according to Yi and Song, 2008).
} 
intermediation, the government has been able to maintain or suppress interest rates at below market-clearing levels.

SOE Reform. SOE reform starting in 1997 helped to release cheap labor from the state sector to the private sector, which has sustained the high private returns to capital during China's economic transition. Under China's planned economy, SOE were the major employers in cities and played the pivotal role of maintaining low unemployment and ensuring social stability. As a result, even unprofitable SOE could survive. By the mid-1990s, the Chinese government realized that its gradualist reform policy could no longer manage the mounting losses of SOE. Beginning in 1997, China moved forward with more aggressive restructuring of large SOE, accomplished through large-scale privatization. The reallocation of labor and capital from SOE to private firms has been a key source of productivity growth in the past decade.

\section{The Benchmark Model}

In this section, we develop a theory of China's housing boom consistent with the institutional background and stylized empirical facts about China and its housing market behavior. In particular, we extend the SSZ model to a setting with an intrinsically valueless asset-housing-and prove that a housing price bubble that grows faster than GDP exists even if housing provides no rents or utilities to investors. For simplicity, we exclude low-income households (workers) from the housing market because their participation has only a level effect but no growth effects on the housing prices. We emphasize a growing bubble because the traditional bubble literature often focuses exclusively on static bubbles or bubbles that grow at most at the same rate as the economy, which is contradicted by the Chinese data. In this section, we illustrate our main story in a twoperiod overlapping-generations (OLG) model. We extend the model to a more realistic setting with multi-period OLG for the quantitative analysis in Section 4.

\section{A. The Environment}

The economy is populated by two-period lived agents with overlapping generations. Agents work when young and consume their savings when old. Agents have heterogeneous skills. In each cohort, half of the population are workers without entrepreneurial skills and the other half are entrepreneurs. Entrepreneurial skills are inherited from parents; we do not allow transition between social classes (for simplification without loss of generality). The total population, $N_{t}$, grows at an exogenous rate $v$.

Before the economy starts, the government owns a fixed $\bar{H}$ unit of housing (land). At the beginning of the first period, the government sells the housing stock to the market (if there is demand) and consumes the proceeds. We assume that foreign capital cannot flow freely into China under capital controls, which rules out foreigners speculating in China's housing market.

Technology. - There are two production sectors and thus two types of firms. Labor is perfectly mobile across the two sectors but capital is not. The first sector is composed 
of conventional firms-F-firms, which, for simplicity, are owned by a representative financial intermediary (e.g., a state-owned bank) and operated as standard neoclassical firms. ${ }^{20}$

The second sector is a newly emerging private sector composed of unconventional firms-E-firms, operated by entrepreneurs. More specifically, E-firms are owned by old (parent) entrepreneurs, who are residual claimants on profits, and they hire their own children as managers. Workers can choose to work for either type of firm.

E-firms are more productive than F-firms but are borrowing constrained-they cannot borrow from each other or from any other sources. As a result, E-firms must self-finance capital investment through their own savings. In contrast, F-firms can rent capital from their representative financial intermediary at a fixed interest rate, $R$. Accordingly, Ffirms can survive in the short run despite inferior technology. Over time, however, labor will gradually reallocate from F-firms to E-firms as the capital stock of E-firms expands. Thus, the economy features a transition stage during which F-firms and E-firms coexist, but the F-sector is shrinking and the E-sector is expanding. When the transition ends, only E-firms exist and the economy becomes a representative-agent growth model with neoclassical features. Our focus in this paper is the transition stage. ${ }^{21}$

The technologies of the two types of firms follow constant returns to scale,

$$
y_{t}^{F}=\left(k_{t}^{F}\right)^{\alpha}\left(A_{t} n_{t}^{F}\right)^{1-\alpha}, y_{t}^{E}=\left(k_{t}^{E}\right)^{\alpha}\left(A_{t} \chi n_{t}^{E}\right)^{1-\alpha},
$$

where $y^{j}, k^{j}$, and $n^{j}$ denote per capita output, capital stock, and labor, respectively, for a type- $j$ firm, $j \in\{E, F\}$. The parameter $\chi>1$ captures the assumption that E-firms are more productive than F-firms. Technological growth in both sectors is constant and exogenous and given by $A_{t+1}=A_{t}(1+z)$. However, during the economic transition, resource reallocation can generate endogenous growth faster than growth in $A_{t}$.

WORKER's Problem. - Workers can deposit their savings into the representative bank and earn a fixed interest rate, $R$. However, workers cannot borrow from banks. Without loss of generality, we also assume that workers do not speculate in the housing market. Allowing workers to invest in housing does not change our main results-although the housing price level would be much larger, the growth rate of housing prices would be unaffected. $^{22}$ This result stays the same because the equilibrium growth rate of housing prices in our model is determined by the rate of return to capital of the entrepreneurs, who are the marginal investors in the "bubbly equilibrium".

\footnotetext{
${ }^{20}$ We can assume that F-firms have market power and our main results do not change qualitatively.

${ }^{21}$ Note that the concept of "transition" in this paper is different from the convention in the neoclassical growth model, where transition means the dynamic path from an initial point toward the steady state. This conventional transition phase shows up in our model after the F-sector disappears. To avoid confusion, we call this neoclassical transition period "post-transition."

${ }^{22}$ The proof is available upon request.
} 
The worker's consumption-saving problem is

$$
\max _{c_{1 t}^{w}, c_{2 t+1}^{w}} \log c_{1 t}^{w}+\beta \log c_{2 t+1}^{w}
$$

subject to $c_{1 t}^{w}+s_{t}^{w}=w_{t}$ and $c_{2 t+1}^{w}=s_{t}^{w} R$, where $w_{t}$ is the market wage rate; $c_{1 t}^{w}, c_{2 t+1}^{w}$, and $s_{t}^{w}$ denote, respectively, consumption when young, consumption when old, and the worker's savings.

The F-Firm's Problem. - In each period, an F-firm maximizes profits by solving the following problem:

$$
\max _{k_{t}^{F}, n_{t}^{F}}\left(k_{t}^{F}\right)^{\alpha}\left(A_{t} n_{t}^{F}\right)^{1-\alpha}-w_{t} n_{t}^{F}-R k_{t}^{F},
$$

where $R$ represents either the rental rate for capital or the deposit rate-that is, the two rates are the same. The first-order conditions imply

$$
w_{t}=(1-\alpha) A_{t}\left(\frac{\alpha}{R}\right)^{\frac{\alpha}{1-\alpha}} .
$$

Note that during the transition, the wage rate, scaled by the level of technology, $w_{t} / A_{t}$, is constant due to a constant rental rate for capital and, accordingly, a constant capitalto-labor ratio, $k_{t}^{F} /\left(A_{t} n_{t}^{F}\right)=(\alpha / R)^{\frac{1}{1-\alpha}}$. When the transition is completed, all F-firms disappear, so equation (4) no longer holds.

The E-Firm's Problem. - Following SSZ (2011), we assume that young entrepreneurs receive a management fee, $m_{t}$, from their parents, which is a fixed $\psi<1$ fraction of the output produced, $m_{t}=\psi\left(k_{t}^{E}\right)^{\alpha}\left(A_{t} \chi n_{t}^{E}\right)^{1-\alpha} \cdot 23$ Therefore, the old entrepreneur's problem can be written as

$$
\max _{n_{t}^{E}}(1-\psi)\left(k_{t}^{E}\right)^{\alpha}\left(A_{t} \chi n_{t}^{E}\right)^{1-\alpha}-w_{t} n_{t}^{E}
$$

\footnotetext{
${ }^{23} \mathrm{SSZ}$ also provide a micro-foundation for a young entrepreneur's management fee as a fixed fraction of output: there exists an agency problem between the manager and owner of the business. The manager can divert a positive share of the firm's output for her own use. Such opportunistic behavior can be deterred only by paying managers a compensation that is at least as large as the funds they could steal, which is a share $\psi$ of output. An alternative interpretation of $\psi$ is that it reflects the government policy that transfers resources from the capital owners (the old entrepreneurs) to the managers (the young entrepreneurs). See Miao, Wang, and Zhou (2016), who study housing bubbles based on firm-level policy distortions.
} 
The first-order conditions imply a linear relationship between $n_{t}^{E}$ and $k_{t}^{E}$ :

$$
n_{t}^{E}=[(1-\psi) \chi]^{\frac{1}{\alpha}}\left(\frac{R}{\alpha}\right)^{\frac{1}{1-\alpha}} \frac{k_{t}^{E}}{\chi A_{t}} .
$$

Such a linear relationship is obtained because of a constant wage rate, which results from the constant interest rate, $R$. Accordingly, labor is reallocated to E-firms at a speed equal to the growth of E-firm capital stock. Substituting (6) into (5) gives E-firm profit: $\pi\left(k_{t}^{E}\right)=(1-\psi)^{\frac{1}{\alpha}} \chi^{\frac{1-\alpha}{\alpha}} R k_{t}^{E} \equiv \rho^{E} k_{t}^{E}$, where the first equality is based on equation (6). Whenever F-firms exist, the return to capital for E-firms, $\rho^{E} \equiv(1-\psi)^{\frac{1}{\alpha}} \chi^{\frac{1-\alpha}{\alpha}} R$, is a constant because $n_{t}^{E}$ increases linearly in $k_{t}^{E}$. Similar to SSZ, we impose the following assumption about E-firm relative productivity, such that an entrepreneur's return to capital is higher than the deposit rate, $R$, during the transition: $\chi>\chi \equiv(1-\psi)^{-\frac{1}{1-\alpha}}$.

The Young Entrepreneur's Problem. - The young entrepreneur decides consumption and portfolio allocations in housing investment, bank deposits, or physical capital investment. The rate of return to capital investment is simply $\rho^{E}$. We assume that the balanced growth rate, which equals the rate of return to housing investment at a steady state, is greater than the bank deposit rate-that is, $(1+z)(1+v)>R$. As a result, the entrepreneur will always prefer investing in housing to depositing funds in the bank. Given housing prices, $P_{t}^{H}$, the young entrepreneur faces a two-stage problem.

In the first stage, a young entrepreneur's consumption-saving problem is:

$$
\max _{s_{t}^{E}} \log \left(m_{t}-s_{t}^{E}\right)+\beta \log R_{t+1}^{E} s_{t}^{E},
$$

where $R_{t+1}^{E} \equiv \max \left\{\rho^{E}, P_{t+1}^{H} / P_{t}^{H}\right\}$ is the rate of return for entrepreneur's savings and depends on the entrepreneur's portfolio choices. First-order conditions give the optimal savings of the young entrepreneur, $s_{t}^{E}=m_{t} /\left(1+\beta^{-1}\right)$.

In the second stage, the young entrepreneur chooses portfolio allocations given total savings, $s_{t}^{E}$. The fraction $\phi_{t}^{E}$ of savings is invested in capital, such that $K_{t+1}^{E}=\phi_{t}^{E} s_{t}^{E} N_{t}$, where $K_{t+1}^{E}=k_{t+1}^{E} N_{t+1}$ is total E-firm capital. The remaining $\left(1-\phi_{t}^{E}\right)$ fraction of savings is invested in housing, such that $P_{t}^{H} H_{t}^{E}=\left(1-\phi_{t}^{E}\right) s_{t}^{E} N_{t}$, where $H_{t}^{E}$ denotes the total housing stock purchased by young entrepreneurs in period $t$. Throughout this paper, we ensure that there exists an interior solution for the portfolio choice, such that the following no-arbitrage condition holds:

$$
\frac{P_{t+1}^{H}}{P_{t}^{H}}=\rho_{t+1}^{E},
$$

where $\rho_{t+1}^{E}=\rho^{E}$ (a constant) during the transition. Hence, an old entrepreneur's income is simply $\rho^{E} s_{t}^{E}$. The above condition simply says that the entrepreneur's rate of return to 
housing and rate of return to capital must be equal in a bubbly equilibrium.

The BANK's Problem. - For expositional purpose, we assume that for each period the bank simply absorbs deposits from young workers, lends out to F-firms at interest rate $R$, and invests the rest in foreign bonds with the same rate of return $R$ (as in SSZ, 2011). The resulting housing price dynamics would be similar if we instead allowed the bank to invest in housing on behalf of the workers with two additional assumptions: (i) the bank's only source of funding is the household deposit (although they can lend to foreigners by investing in foreign bonds) $;{ }^{24}$ and (ii) the bank is required to provide funds to meet the capital demand of F-firms before they can invest in housing. ${ }^{25}$ Accordingly, the demand for housing by state banks or F-firms is simply a fraction of household savings after meeting F-firm capital demand. Since banks are borrowing constrained in the international capital market, this ensures that banks or F-firms are not the marginal investors.

Timeline. - To summarize, in each period economic events unfold as follows:

1) At the beginning of period $t$, E-firms and F-firms produce. Each young worker gets paid a real wage, $w_{t}$, regardless of which sector the young worker works in. Each young entrepreneur gets $m_{t}$.

2) Both the young entrepreneur and young worker make consumption and savings decisions. In addition, the young entrepreneur makes a portfolio choice, $\phi_{t}^{E}$.

3) The housing market opens. The old entrepreneur sells housing stock held in the previous period, $H_{t-1}^{E}$. The young entrepreneur makes a portfolio decision, $\phi_{t}^{E}$.

4) F-firms repay their capital rents to the bank.

5) The currently old workers and entrepreneurs consume and die.

Law of Motion. - Since the E-firm is self-financed, the law of motion for E-firm capital stock follows

$$
K_{t+1}^{E}=\phi_{t}^{E} \frac{\rho_{t}^{E} \psi}{(1-\psi) \alpha} \frac{1}{1+\beta^{-1}} K_{t}^{E}
$$

\footnotetext{
${ }^{24}$ The Chinese government has strict control over capital inflow other than foreign direct investment (e.g., foreign borrowing or allowing foreigners to purchase houses). Specifically, portfolio investment is controlled by quotas and foreign borrowing is subject to a ceiling (for short-term borrowing) or approval requirements (for long-term borrowing). Accordingly, during 2005-2010, the overall non-foreign-direct-investment capital account has on average a net outflow of 0.2 percent of GDP (Bayoumi and Ohnsorge, 2013).

${ }^{25}$ In China, an important task for state-owned banks is to finance SOE production to maintain employment and thus social stability (see Bai, et al., 2000).
} 
where $\rho_{t}^{E}=\rho^{E}$ for all periods during the transition. As shown later, in this simple economy, the entrepreneur's portfolio share in physical capital, $\phi_{t}^{E}$, is constant, which together with a constant $\rho^{E}$ implies that the dynamics of the model have an AK feature during the transition: the growth rate of E-firm capital is constant. Similarly, we can obtain the implicit law of motion for housing demand as:

$$
P_{t}^{H} \bar{H}=\left(1-\phi_{t}^{E}\right) \frac{\rho_{t}^{E} \psi}{(1-\psi) \alpha} \frac{1}{1+\beta^{-1}} K_{t}^{E},
$$

where we have used the housing market-clearing condition, $H_{t}^{E}=\bar{H}$.

Post-TRANSITION EQUILIBRIUM. - We now characterize the equilibrium in the posttransition stage. Since $n_{t}^{E}=1$, E-firm profit is

$$
\pi\left(k_{t}^{E}\right)=\alpha(1-\psi)\left(k_{t}^{E}\right)^{\alpha}\left(A_{t} \chi\right)^{1-\alpha} .
$$

Note that $\pi\left(k_{t}^{E}\right)$ features decreasing returns to scale at this stage. The rate of return to E-firm capital is simply $\rho_{t+1}^{E}=\alpha(1-\psi)\left(k_{t+1}^{E}\right)^{\alpha-1}\left(A_{t+1} \chi\right)^{1-\alpha}$.

The Steady State. - The steady state of the economy is reached only in the posttransition stage. Since all per capita variables (except labor inputs and housing) grow at the rate $A_{t}$, we detrend them as $\widehat{x}_{t}=x_{t} / A_{t}$.

At the steady state, the law of motion for capital (9) implies

$$
\widehat{k}^{E *}=\left[\frac{\psi \phi^{E *} \chi^{1-\alpha}}{\left(1+\beta^{-1}\right)(1+z)(1+v)}\right]^{\frac{1}{1-\alpha}} .
$$

Since $\rho^{E *}=\alpha(1-\psi)\left(\widehat{k}^{E *} / \chi\right)^{\alpha-1}$, we have

$$
\rho^{E *}=\alpha(1-\psi) \frac{\left(1+\beta^{-1}\right)(1+z)(1+v)}{\psi \phi^{E *}} .
$$

Equation (13) implies that the rate of return to capital is negatively related to the E-firm portfolio share in physical capital, $\phi^{E *}$.

The equilibrium portfolio allocation $\phi^{E *}$ can be solved by the no-arbitrage condition. Since the supply of housing is fixed, the growth rate of housing prices, denoted as $\rho_{t+1}^{H} \equiv P_{t+1}^{H} / P_{t}^{H}$, equals the balanced growth rate, $(1+z)(1+v)$, in the steady state. As a result, the no-arbitrage condition implies the E-firm steady-state portfolio share in physical capital is:

$$
\phi^{E *}=\alpha(1-\psi)\left(1+\beta^{-1}\right) / \psi .
$$


Intuitively, the larger the rate of return to E-firm capital, as captured by $\alpha(1-\psi)$, the larger the share of entrepreneurial savings in physical capital. On the other hand, the larger $\psi$ and $\beta$, which imply, respectively, a larger income share for and saving propensity of the young entrepreneur, the lower the return to physical capital and thus the lower the share of entrepreneurial savings in physical capital.

Note that, in our model, due to agency frictions (i.e., $\psi>0$ ), there is a wedge between the private and social rates of return to capital. The social rate of return to E-firm capital is simply the marginal product of E-firm capital, denoted as $M P K^{E} \cdot{ }^{26}$ Given the definition of $\rho^{E}$, we then have $\rho^{E}<M P K^{E}$. Hence, in contrast to the standard bubble theory, dynamic inefficiency is a sufficient, but not necessary, condition for housing bubbles to exist in the long run. This finding has dramatically different and important welfare implications from those in the traditional bubble literature, as we show below.

\section{B. Characterizing the Bubbly Equilibrium}

In this subsection, we explore the equilibrium with housing bubbles. We first discuss the necessary conditions for housing bubbles to exist and then show under what conditions an equilibrium path with housing bubbles can be achieved. Next, we derive the growth rate of housing prices relative to that of aggregate output. Finally, we explore the normative implications of bubbles.

EXISTENCE OF BubBles. - Note that there always exists an equilibrium without bubbles in our model - that is, all financial resources are invested in capital and $\phi_{t}^{E}=1$ for all $t$. We call this equilibrium the "fundamental equilibrium", which must be understood first to know under what conditions a bubbly equilibrium can emerge.

Consider the steady state first. For a housing bubble to exist in the steady state (i.e., $\left.\phi^{E *}<1\right)$, in the fundamental equilibrium, the rate of returns to E-firm capital must be below the balanced growth rate. In other words, the economy is dynamically "inefficient" from the perspective of the entrepreneurs. Intuitively, when returns to capital are so low in the fundamental equilibrium, it is optimal for entrepreneurs to divert savings into housing as an alternative store of value. This condition, together with (14), implies the following parameter restriction on the bubbly equilibrium:

$$
\alpha(1-\psi)\left(1+\beta^{-1}\right)<\psi,
$$

or $\psi>\psi \equiv \alpha\left(1+\beta^{-1}\right) /\left[1+\alpha\left(1+\beta^{-1}\right)\right]$. Intuitively, a larger $\psi$ makes the bubble more likely to occur in two ways. First, it directly reduces the entrepreneur's rate of return to E-firm capital. Second, by increasing the young entrepreneur's output share, it increases the capital stock accumulated by the young, thus lowering the marginal product

\footnotetext{
${ }^{26}$ Implicitly, the planner solves a constrained optimization problem without agency frictions but with financial market imperfectness as in the benchmark model.
} 
of E-firm capital. ${ }^{27}$ In addition, the assumption that $R<(1+z)(1+v)$ ensures that the rate of return to housing investment in the post-transition stage is higher than the bank deposit rate, which serves as another necessary condition for bubbles to exist.

We are now able to characterize the conditions for bubbles to exist in both the transition and the post-transition stages. Assumption (15), together with the law of motion for capital, (9), implies that in the fundamental equilibrium,

$$
K_{t+1}^{E}>\rho_{t}^{E} K_{t}^{E}, \forall t
$$

This is so because the wedge between $K_{t+1}^{E}$ and $\rho_{t}^{E} K_{t}^{E}$ is a constant and this constant exceeds 1 in the fundamental equilibrium. Accordingly, given that (16) is satisfied at the steady state, it must be satisfied for all previous periods. Forwarding (16) one period and noticing that, with full depreciation of capital, $K_{t+1}^{E}=I_{t}^{E}$, where $I_{t}^{E}$ is investment in physical capital, we have

$$
I_{t+1}^{E}>\rho_{t+1}^{E} I_{t}^{E}, \forall t
$$

The inequality, (17), is analogous to the necessary conditions for the existence of bubbles in the model of Abel et al. (1989, "AMSZ" hereafter). Intuitively, housing bubbles are possible if there exists a sequence of investments with costs exceeding the income flow it generates in all periods.

The inequality, (17), implies that in a bubbly equilibrium, young entrepreneurs would voluntarily reduce their capital investment and hold housing in their portfolios, with the expectation that the revenues from selling housing will be no less than their forgone income from capital investment. To see this point, note that equation (9) implies that in the fundamental equilibrium,

$$
I_{t+1}^{E}=(1+\varepsilon) \rho_{t+1}^{E} I_{t}^{E}
$$

where $\varepsilon \equiv \psi /\left[(1-\psi) \alpha\left(1+\beta^{-1}\right)\right]-1>0$. Take the total derivative with respect to (18) and let $d I_{t}^{E}=-\left(P_{t}^{H} \bar{H}-0\right)$; that is, the resources generated from a reduction in capital investment (the left-hand side) are invested in housing (the right-hand side). We then have the inequality $P_{t+1}^{H} / P_{t}^{H}>\rho_{t+1}^{E}$. In other words, the rate of return to housing investment would be greater than the rate of return to capital if entrepreneurial savings were all invested in physical capital. As a consequence, expecting the inequality (17) to hold for all future periods and thus a positive future demand for housing, the young entrepreneurs in period $t$ opt to divert savings into housing, which would raise the housing price, $P_{t}^{H}$, until the no-arbitrage condition, $P_{t+1}^{H} / P_{t}^{H}=\rho_{t+1}^{E}$, holds.

Our result is in contrast to that in the traditional bubble literature in two aspects. First, the traditional bubble literature (e.g., the original AMSZ test) evaluates dynamic (in)efficiency based on the economy-wide rate of return to capital, rather than the rate of

\footnotetext{
${ }^{27}$ On the other hand, the incentive for entrepreneurs to hold bubbles does not depend on whether there exists a wedge between the social and private returns to capital.
} 
return to capital for marginal investors (i.e., the productive entrepreneurs in our model) ${ }^{28}$ Second, in the traditional bubble literature, the social and private returns to capital are assumed to be the same. In contrast, they are not the same in our model because a wedge exists between the two. Thus, condition (16) needs to hold only with respect to the private returns to E-firm capital. This implies that a bubbly equilibrium may exist in our model under dynamic efficiency, which we now explore further.

Dynamic efficiency implies that the steady-state $M P K^{E}$ in the fundamental equilibrium is larger than the balanced growth rate,

$$
\left.M P K^{E *}\right|_{\phi_{E}=1}>(1+z)(1+v) .
$$

With (13), condition (19) requires the following parameter restriction:

$$
\psi<\alpha\left(1+\beta^{-1}\right)
$$

Intuitively, the smaller $\psi$ is, the smaller the steady-state capital is and the larger its marginal product. Also, similar to standard OLG models, a higher $\alpha$ or a lower $\beta$ makes the economy less likely to be dynamically inefficient. A combination of (15) and (20) gives further parameter restrictions for bubbles to exist when the economy is dynamically efficient:

$$
\alpha(1-\psi)\left(1+\beta^{-1}\right)<\psi<\alpha\left(1+\beta^{-1}\right)
$$

The Equilibrium Path. - Given the bubble equilibrium, what ensures that rational entrepreneurs will choose their asset portfolios each period to reach such an equilibrium? Note that apart from the two equilibrium sequences of housing prices (or investment) mentioned above, there exist many other equilibrium paths along which the per capita holding of bubble assets converges to zero. ${ }^{29}$ It can be shown that the young entrepreneur's portfolio share of savings in housing assets is characterized by the following first-order difference equation:

$$
h_{t+1}^{E}=\frac{h_{t}^{E}}{1-h_{t}^{E}} \frac{(1-\psi) \alpha\left(1+\beta^{-1}\right)}{\psi},
$$

where $h_{t}^{E} \equiv 1-\phi_{t}^{E}$. The first argument on the right-hand side, $h_{t}^{E} /\left(1-h_{t}^{E}\right)$, is an increasing and convex function of $h_{t}^{E}$. This equation implies that there are two steady states for $h_{t}^{E}$. At one steady state, there is no bubble, $h_{t}^{E}=0$ for all $t$. At the other, $h_{t}^{E}=h^{E *}=1-(1-\psi) \alpha\left(1+\beta^{-1}\right) / \psi>0$, so there is a bubble and the bubbly steady state is a saddle point. Moreover, for any initial value $h_{0}^{E} \in\left(0, h^{E *}\right)$, the economy will

\footnotetext{
${ }^{28}$ As argued by Giglio and Severo (2012), looking at the average rate of return in the economy is not sufficient to judge the dynamic (in)efficiency of market allocations because there might be an over-accumulation among those who cannot park funds in productive assets (e.g., Martin and Ventura, 2012).

${ }^{29}$ Such equilibrium paths, according to Tirole (1985), are called asymptotic bubbleless.
} 
converge to a bubbleless steady state: $\lim _{t \rightarrow \infty} h_{t}^{E}=0 .{ }^{30}$ Only when $h_{0}^{E}=h^{E *}$ will the equilibrium path converge to the bubbly steady state in the long run.

Alternatively, we can show the dynamics of the system using a phase diagram of $\widehat{p}_{t}^{H}$ and $\widehat{k}_{t}^{E}$. Appendix A shows that in this economy there is a unique saddle path for $\widehat{p}_{t}^{H}$ and $\widehat{k}_{t}^{E}$. For any initial level of E-firm capital $\widehat{k}_{0}^{E}$, when $\widehat{p}_{0}^{H}=\widetilde{p}_{0}^{H} \equiv h^{E *} \psi \rho^{E} \widehat{k}_{0}^{E} /\left[\left(1+\beta^{-1}\right)(1-\psi) \alpha\right]$, the economy will converge to the bubbly steady state at which $\rho^{E *}=(1+z)(1+v)$. For any other $\widehat{p}_{0}^{H}=\left[0, \widetilde{p}_{0}^{H}\right)$, the economy will converge to a bubbleless steady state. A unique feature of our model is that the saddle path is linear during the transition stage due to its AK feature.

To achieve the bubbly equilibrium, it is crucial for entrepreneurs in each period to expect a particular sequence of housing prices that converge to the bubbly steady state. This expectation is driven by the expected strong future demand for housing, which is self-fulfilling and rationalized by the fact that the future rate of capital returns, $\rho_{t}^{E}$, will be sufficiently low in the post-transition stage. Under such an expectation, holding housing today can yield large capital gains tomorrow even if housing has no intrinsic value. Accordingly, it is rational for currently young entrepreneurs to invest in housing even if they live only for a finite number of periods.

Therefore, we assume that the economy starts with an initial portfolio share of housing assets $h_{0}^{E}=1-(1-\psi) \alpha\left(1+\beta^{-1}\right) / \psi$, which gives the following optimal portfolio share in physical capital:

$$
\phi_{t}^{E}=\frac{\alpha\left(1+\beta^{-1}\right)(1-\psi)}{\psi}, \forall t
$$

Equation (23) suggests that the entrepreneurial portfolio share in housing assets is constant along the transition path. Although the short length of household survey data in China (starting from 2011) is not sufficient to exhibit a secular pattern of the share of entrepreneurial savings in housing, the empirical evidence provided in Table 2 suggests that the share of real estate in total fixed assets for non-real estate firms that invest in housing property (unrelated to their original business) is very stable over time: about 14 percent to 15 percent between 2007 and 2013. Such a stable portfolio-share pattern is consistent with our model's prediction about the dynamics of entrepreneur's portfolios in housing assets.

The Growth Rate of Housing Prices Relative to Output. - We now characterize the growth rate of housing prices relative to output.

LEMMA 1: The growth rate of housing prices is equal to the growth rate of E-firm

\footnotetext{
${ }^{30}$ On the other hand, for any initial value $h_{0}^{E}>1-(1-\psi) \alpha\left(1+\beta^{-1}\right) / \psi \equiv \widetilde{h}_{0}^{E}$, the system will explode and violate the transversality condition, so it cannot be in equilibrium.
} 
output in both the transition and post-transition stages.

$$
\frac{P_{t+1}^{H}}{P_{t}^{H}}=\frac{Y_{t+1}^{E}}{Y_{t}^{E}}, \forall t
$$

The intuition for Lemma 1 is as follows. In both the transition and post-transition stages, entrepreneurs' optimal portfolio choices will equalize the rate of return to capital investment and the rate of return to bubbles through arbitrage. In this simple economy, the equilibrium portfolio $\phi_{t}^{E}$ is a constant, as the wedge between $K_{t+1}^{E}$ and $\rho_{t}^{E} K_{t}^{E}$ in the fundamental equilibrium is constant. This gives $K_{t+1}^{E}=\rho_{t}^{E} K_{t}^{E}$ in the bubbly equilibrium. Accordingly, the growth rate of total E-firm output equals the rate of return to capital for entrepreneurs, which in turn equals the growth rate of housing prices according to the no-arbitrage condition. ${ }^{31}$

With Lemma 1, the following proposition captures the growth rate of housing prices relative to that of aggregate output.

PROPOSITION 1: Denoting $\Delta X_{t}$ as the growth rate of $X_{t}$, the growth rate of housing prices exceeds that of aggregate output during the transition and converges to that of aggregate output when the transition ends. Specifically,

$$
\Delta \log P_{t+1}^{H}=\Delta \log Y_{t+1}+\Delta \log \frac{Y_{t}^{E}}{Y_{t}^{E}+Y_{t}^{F}} .
$$

Equation (25) implies that the gap between the growth rate of housing prices and that of aggregate output equals the growth rate of the E-firm share of aggregate output. During the transition, aggregate output growth is a weighted average of the output growth of E-firms and F-firms. Since F-firms keep downsizing because of labor reallocation, this sector's output growth rate is less than that of E-firms, implying a lower growth rate of the aggregate economy than of E-firms. ${ }^{32}$ Therefore, housing prices, which increase at a rate equal to that of E-firm output according to Lemma 1, will grow faster than the growth rate of the economy at this stage. In the post-transition stage, the economy becomes essentially neoclassical: The growth rate of aggregate output equals the growth rate of total E-firm output. As a result, housing prices grow at the same rate as aggregate output, even before reaching the steady state.

\footnotetext{
${ }^{31}$ More formally, the growth rate of total E-firm output is given by

$$
\frac{Y_{t+1}^{E}}{Y_{t}^{E}}=\frac{Y_{t+1}^{E}}{K_{t+1}^{E}} \frac{K_{t+1}^{E}}{K_{t}^{E}} \frac{K_{t}^{E}}{Y_{t}^{E}}=\frac{\rho_{t+1}^{E}}{(1-\psi) \alpha} \rho_{t}^{E} \frac{(1-\psi) \alpha}{\rho_{t}^{E}}=\rho_{t+1}^{E} .
$$

${ }^{32}$ More formally, the growth rate of total F-firm output follows

$$
\frac{Y_{t+1}^{F}}{Y_{t}^{F}}=\frac{R K_{t+1}^{F} / \alpha}{R K_{t}^{F} / \alpha}=\frac{K_{t+1}^{F}}{K_{t}^{F}} .
$$
}


Furthermore, standard algebra shows that the E-firms' share of total output is given by

$$
\log \frac{Y_{t}^{E}}{Y_{t}^{E}+Y_{t}^{F}}=\log \frac{N_{t}^{E} / N_{t}}{1-\psi+\psi N_{t}^{E} / N_{t}} .
$$

Therefore, together with Proposition 1, equation (26) implies that the growth rate of housing prices relative to that of aggregate output depends positively on the growth rate of the E-firm employment share, $N_{t}^{E} / N_{t}$. Note that during the transition, the growth rate of the E-firm employment share is constant due to the constant growth rate of the E-sector capital stock, as implied by the AK feature. ${ }^{33}$ This implies a persistently larger growth rate of housing prices than that of aggregate output. For a similar composition effect, the aggregate rate of return to capital increases during the transition, despite the constant rate of return to capital for both E-firms and F-firms. ${ }^{34}$

In our model economy, the key to delivering a housing price growth rate faster than the GDP growth rate is a prolonged transition stage featuring labor reallocation from unproductive to productive (but financially constrained) firms. During this transition, the high rate of return to capital for entrepreneurs is sustained by surplus labor in the F-sector and prolonged by borrowing constraints in the E-sector. ${ }^{35}$ Cheap surplus labor is expected to be exhausted only after the transition ends-when returns to capital start to decrease. It is precisely this trajectory of returns to capital that entices productive agents (entrepreneurs) to invest in the housing market and become marginal buyers. The unproductive agents (workers or F-firms) can also invest in housing, but they will not be the marginal buyers.

This finding is in contrast to the results of Martin and Ventura (2012). In their paper, the marginal buyers of bubble assets are the unproductive agents who face a low rate of return to capital (as in the traditional bubble literature). Consequently, their model predicts slower-than-GDP growth in the housing bubble, which is inconsistent with the Chinese data. Moreover, in their paper, bubbles improve allocative efficiency by crowding in investment of productive firms-which is again inconsistent with the Chinese data in Section 2. In contrast, as the next section shows, bubbles in our model can worsen allocative efficiency by crowding out investment of productive firms-a serious concern

${ }^{33}$ More formally, the growth rate of the E-sector employment share is

$$
\frac{N_{E t+1} / N_{t+1}}{N_{E t} / N_{t}}=\frac{K_{E t+1} / N_{t+1}}{K_{E t}(1+z) / N_{t}}=\frac{\rho_{t}^{E}}{(1+z)(1+v)} .
$$

${ }^{34}$ More formally, the aggregate rate of return to capital is computed as

$$
\rho_{t}=\frac{\rho^{E} K_{t}^{E}+\rho^{F} K_{t}^{F}}{K_{t}^{E}+K_{t}^{F}}=\frac{R}{1-\frac{N_{t}^{E}}{N_{t}}\left[1-\chi((1-\psi) \chi)^{-\frac{1}{\alpha}}\right]}
$$

\footnotetext{
${ }^{35}$ Note that in any rational bubble theory with neoclassical features, housing price growth can be temporarily very high as the rate of return to capital is initially high. However, as our counterfactual experiment later shows, it is difficult for such types of models to quantitatively explain the scale, both in absolute terms and relative to GDP growth, and length of China's housing bubble.
} 
of the Chinese government for many years.

We also check the robustness of our model's predictions for housing price growth by extending our benchmark economy to alternative settings where (i) housing services are valued; (ii) the economy consists of both labor-intensive and capital-intensive sectors such that the labor share of SOE does not converge to zero; (iii) entrepreneurs can borrow against housing; and (iv) housing bubbles are stochastic. We show analytically that in each of these alternative setups, the model robustly predicts that housing prices will grow faster than aggregate income during the economic transition. ${ }^{36}$

ECONOMic Consequences of a Growing Bubble. - An interesting issue concerns the normative implications of bubbles in our model. Because bubbles can exist in our model without dynamic inefficiency, they may reduce, rather than increase, social welfare. We now explore the welfare implications of growing bubbles in detail.

We first study the implications of bubbles for aggregate consumption in both the transition and post-transition stages. With condition (20), the law of motion for capital (9) implies that in the fundamental equilibrium, at each period $t$,

$$
K_{t+1}^{E}<M P K_{t}^{E} \cdot K_{t}^{E} .
$$

In other words, investment in bubbles is not optimal for the social planner, despite the incentives for entrepreneurs to invest in housing. The reason is simple: given the sufficiently high marginal product of E-firm capital, housing bubbles reduce the resources available for aggregate consumption by crowding out productive investment. ${ }^{37}$

To allow bubbles to reduce total entrepreneurial consumption, we further assume that

$$
\psi<\alpha\left(1+\beta^{-1}\right)[\psi+\alpha(1-\psi)] .
$$

Note that $\psi+\alpha(1-\psi)$ is the share of E-firm output accrued to young and old entrepreneurs. Since $\psi+\alpha(1-\psi)<1$, the inequality (28) is sufficient for dynamic efficiency, (20), to hold. ${ }^{38}$ To derive the effects of bubbles on each type of agent, we define the period- $t$ aggregate consumption of agent type- $j \in\{w, E\}$ as $\widehat{c}_{t}^{j} \equiv \widehat{c}_{1, t}^{j}+\widehat{c}_{2, t}^{j}(1+v)^{-1}$.

PROPOSITION 2: Given that (15) and (28) are both satisfied, a housing bubble reduces aggregate consumption and the welfare of both entrepreneurs and workers.

The intuition is as follows. In addition to forgone returns to capital, entrepreneurial housing investment reduces the lifetime income of future entrepreneurs and, thus, nega-

\footnotetext{
${ }^{36}$ These results are available upon request.

${ }^{37}$ A similar wedge between social and private rates of return for capital occurs in the endogenous growth models of Grossman and Yanagawa (1993) and King and Ferguson (1993), in which the labor productivity of individual firms depends positively on the aggregate stock of capital.

${ }^{38} \mathrm{~A}$ combination of $(15)$ and $(28)$ implies $(1-\psi)(1-\alpha)<\psi$, which is guaranteed by $m_{t} \geq w_{t}$, the necessary condition for the young entrepreneur to work as a manager rather than a worker.
} 
tively impacts their consumption. ${ }^{39}$ It is easy to show that during the transition, since the rate of return to capital is constant, a reduction in lifetime income reduces entrepreneurs' lifetime utility. In Appendix B, we also show that bubbles reduce the entrepreneurial lifetime utility at the steady state. For entrepreneurs born during the post-transition stage, a sufficient condition for welfare loss is $\alpha\left(1+\beta^{-1}\right)>1-\alpha^{2}$.

Regarding the impact of housing bubbles on worker consumption, note that the wage rate, a constant along the transition, is unaffected by the bubble during the transition. Hence, the welfare of workers during the transition is unaffected by the bubble. However, when the transition ends, workers' lifetime utility decreases as a result of the housing bubble. This is because worker wage income starts to depend positively on E-firm capital stock, while the rate of return to savings (the deposit rate) is still fixed.

The next question is whether it is desirable to burst a bubble once it exists, given that bubbles crowd out productive investment. The answer is no. In our economy, the housing bubble serves as a store of value that enables young entrepreneurs to finance retirement consumption when old. Eliminating the bubble will therefore erode the retirement wealth of old entrepreneurs who hold housing when the bubble bursts. To ensure that no household is left worse off after the bubble bursts, the policymaker needs to compensate old entrepreneurs for their losses-say, by issuing government bonds to current-period young entrepreneurs. But the resources needed to compensate old entrepreneurs are the same resources that would have been released by young entrepreneurs for capital accumulation. This circumstance implies that the policymaker is simply substituting another form of a bubble for housing without crowding in productive investment. Indeed, our quantitative exercise below suggests that bursting a housing bubble would reduce the welfare for the majority of cohorts alive at that time.

\section{Quantitative Analysis}

This section brings the model to the data. To facilitate calibrations, we first extend our two-period benchmark model to a multi-period model. In the model, agents live for $J$ periods, are born with zero wealth, and cannot die with negative wealth. Workers supply one unit of labor each period. They retire after $J^{R}$ years of work. Young entrepreneurs work for old entrepreneurs in the first $J^{E}$ periods of life. For simplicity, we assume that an age- $j\left(j<J^{E}-1\right)$ young entrepreneur can only make deposits in the bank with a fixed interest rate, $R$. From age $J^{E}-1$ on, she can have a portfolio choice by purchasing housing or investing in her own business. In this economy, we assume the capital depreciation rate $\delta<1$.

\footnotetext{
${ }^{39}$ Given the initial capital stock and constant returns to capital, the permanent incomes of old and young entrepreneurs alive in the first period are unchanged when a housing bubble is introduced.
} 


\section{A. The Quantitative Multi-period Model}

The F-firm's problem is similar to that in the benchmark model:

$$
\max _{k_{t}^{F} n_{t}^{F}}\left(k_{t}^{F}\right)^{\alpha}\left(A_{t} n_{t}^{F}\right)^{1-\alpha}-w_{t} n_{t}^{F}-R^{l} k_{t}^{F}+(1-\delta) k_{t}^{F} .
$$

For calibration purposes, we assume that lending to an F-firm is subject to a constant iceberg cost, $\xi$, which represents the intermediation cost. In equilibrium, the lending rate for F-firms is $R^{l}=R /(1-\xi)$.

An age- $j$ old entrepreneur in time $t$ solves the following problem:

$$
\pi\left(k_{j, t}^{E}\right)=\max _{n_{j, t}^{E}}\left(1-\tau_{t}^{y}\right)(1-\psi)\left(k_{j, t}^{E}\right)^{\alpha}\left(A_{t} \chi n_{j, t}^{E}\right)^{1-\alpha}-w_{t} n_{j, t}^{E}+(1-\delta) k_{j, t}^{E}
$$

where $k_{j, t}^{E}$ and $n_{j, t}^{E}$, respectively, denote the capital and labor deployed by an age- $j$ old entrepreneur at period $t$. We can derive the rate of returns for E-firm capital as

$$
\rho_{t}^{E} \equiv \pi\left(k_{j, t}^{E}\right) / k_{j, t}^{E}=\alpha(1-\psi)\left(1-\tau_{t}^{y}\right)^{\frac{1}{\alpha}}\left[(1-\alpha)(1-\psi) A_{t} \chi / w_{t}\right]^{\frac{1-\alpha}{\alpha}}+1-\delta
$$

Note that, despite the heterogeneity in capital stock, the rate of return to capital is the same for all entrepreneurs alive in period $t$ under the Cobb-Douglas production function.

For calibration purposes, we assume that E-firm production is subject to a time-varying output wedge, $\tau_{t}^{y}$. The purpose of introducing this wedge is to target the time path of the private employment share in China. ${ }^{40}$ Such an output wedge may capture, in reality, the preferential or distortionary policy toward private firms. For example, in the early stage of privatization, the Chinese government provided various support (e.g., credits, tax deductions) to private firms, which encouraged their fast growth. ${ }^{41}$ This support would show up as an implicit output subsidy to E-firms $\left(\tau_{t}^{y}<0\right)$. Over time, however, such preferential policies have begun to be replaced by various government policies that restrict the growth of private firms (e.g., entry barriers for private firms into "strategic" industries and a heavy tax burden), which in turn contributed to the so-called "Guo Jin Min Tui" (the state advances and the private sector retreats). ${ }^{42}$ This policy

\footnotetext{
${ }^{40}$ Quantitatively, without the output wedge, housing prices still grow faster than GDP during the transition stage. However, the increase of the private employment share will slow down. Accordingly, the simulated housing prices and housing price-to-GDP ratio grow at a slower rate than their benchmark counterparts.

${ }^{41}$ Specifically, on June 29, 2002, the Ninth National People's Congress Standing Committee passed the Law of the People's Republic of China on Promotion of Small and Medium-Sized Enterprise, which was implemented on January 1, 2003. In 2005, the State Council issued "Several Opinions of the State Council on Encouraging, Supporting, and Guiding the Development of Individual and Private Economy and Other Non-public Sectors of the Economy," also called the "Thirty Six Items for the Non-public Economy," to support the development of private enterprises via preferential credit and tax policies.

${ }^{42}$ For example, in 2007, the state government issued a document (the 39th Decree), which requests a transition from preferential corporate income tax rates to legal tax rates. According to this document, those who enjoyed a 15 percent corporate income tax rate before 2008 would have tax rates of 18 percent, 20 percent, 22 percent, 24 percent, and 25 percent for each year between 2008 and 2012, respectively.
} 
distortion would show up in our model as an increase in the value of $\tau_{t}^{y}$. Since, in reality, government policies affect the overall profitability of private firms, we assume that such an output wedge also applies to young entrepreneurs' managerial compensation.

For a worker of age $i$ in period $q$, the problem for the remainder of her life is

$$
\max \sum_{j=i}^{J} \beta^{j-i} \log c_{j, t}^{w},
$$

subject to

$$
\begin{aligned}
c_{j, t}^{w}+s_{j, t}^{w} & =w_{t}+R s_{j-1, t-1}^{w}, \quad \text { for } j<J^{R}, \\
c_{j, t}^{w}+s_{j, t}^{w} & =R s_{j-1, t-1}^{w}, \quad \text { for } j \geq J^{R}, \\
s_{J, t}^{w} & =0, s_{0, t-1}^{w}=0,
\end{aligned}
$$

where the subscript $t \equiv q+j-i$ is the calendar time for the age- $i$ agent to become age $j$.

An entrepreneur of age $i$ in period $q$ has the following consumption-saving problem:

$$
\max \sum_{j=i}^{J} \beta^{j-i} \log c_{j, t}^{E},
$$

subject to

$$
\begin{aligned}
c_{j, t}^{E}+s_{j, t}^{E} & =m_{t}+R s_{j-1, t-1}^{E}, \quad \text { for } j<J^{E}-1, \\
c_{j, t}^{E}+s_{j, t}^{E} & =\rho_{t}^{E} s_{j-1, t-1}^{E}, \quad \text { for } j \geq J^{E}-1, \\
s_{j, t}^{E} & \geq 0 \text { for } j \geq J^{E}-1, \\
s_{J, t}^{E} & =0, s_{0, t-1}^{E}=0 .
\end{aligned}
$$

Here again, for the no-arbitrage condition to hold, we assume that an inner solution to the entrepreneurial portfolio choice exists. Given savings, $s_{j, t}^{E}$, the age- $j$ entrepreneur at period $t$ makes the portfolio choice, $\phi_{j, t}^{E}$.

PROPOSITION 3: There exists an equilibrium in which all entrepreneurs alive in period $t$ will invest the same share of wealth in housing; that is, $\phi_{j, t}^{E}=\phi_{t}^{E}$, for $j \in$ $\left[J^{E}-1, J-1\right]$.

Proposition 3 allows us to derive the following equations for aggregate capital and housing stock in equilibrium: 


$$
\begin{aligned}
K_{t+1}^{E} & =\phi_{t}^{E} \sum_{j=J^{E}-1}^{J-1} N_{j, t}^{E} s_{j, t}^{E}, \\
P_{t}^{H} H_{t}^{E} & =\left(1-\phi_{t}^{E}\right) \sum_{j=J^{E}-1}^{J-1} N_{j, t}^{E} s_{j, t}^{E},
\end{aligned}
$$

where $N_{j, t}^{E}$ denotes the number of age- $j$ entrepreneurs at period $t$. Therefore, we can solve the aggregate labor demand and portfolio choices by aggregation. Appendix $\mathrm{C}$ describes the numerical algorithm to solve for the calibrated economy.

\section{B. Calibration}

We use data from the NBSC to calibrate the model. The model economy starts in 1998, when China began to privatize its SOEs. Each period in our model corresponds to one calendar year.

Consider the first set of parameters, whose values are set exogenously. Agents in our model enter the economy at age 22 and live an additional 50 years. This is consistent with an average life expectancy for males and females of 71.4 years according to the 2000 Chinese Population Census. Workers retire after 30 years. The population growth rate is set to $v=0.03$, consistent with the average urban population growth rate in China during 2002-2012. ${ }^{43}$

In terms of technology parameters, the capital income share is set to $\alpha=0.5$, consistent with Bai, Hsieh, and Qian (2006). ${ }^{44}$ The capital depreciation rate is set to $\delta=0.1$, which is the average depreciation rate between 1998 and 2012, computed using the method of Bai, Hsieh, and Qian (2006). The land supply is normalized to $\bar{H}=1$ and the bank deposit rate is set to $R=1.0175$, following SSZ (2011). Finally, the initial assets of the workers and retirees are set to match wealth in the initial steady state with only F-firms.

Now we turn to the second set of parameters, whose values are set endogenously to target certain data moments. We calibrate $\beta=0.994$ to target the average 40 percent aggregate savings rate between 1998 and 2012. We then set $\psi=0.53$ to target the aggregate 20 percent rate of returns to capital in 1998. Following SSZ, we calibrate the productivity parameter of E-firms to be $\chi=5.64$ to target the following moment: The capital-to-output ratio of Chinese SOE is 2.65 times that of domestic private firms. The iceberg cost $\xi$ is set to 0.0693 to target the 0.093 marginal product of capital (MPK) for SOEs. The rate of labor-augmented technological growth is set to $z=3.8$ percent to

\footnotetext{
${ }^{43}$ Urban population growth may be endogenously driven by rural-urban migration, which in turn could be an outcome of labor reallocation from SOE to private firms. We view this as an interesting extension for future research.

${ }^{44}$ In our model, since housing does not provide services and is in fixed supply, our measured capital stock corresponds to the concept of total reproducible capital stock, which we construct following the method of Bai, Hsieh, and Qian (2006).
} 
target the average 10 percent growth rate of GDP during 1998-2012.

The initial entrepreneurial wealth is set to target an initial employment share of private firms in 1998. According to NBSC data, the employment share of private firms (DPE $+\mathrm{FE}$ ) in total employment was 17 percent in 1998. Accordingly, the initial life-cycle distribution of wealth for managers and entrepreneurs is a scaled-down version of the life-cycle distribution of wealth of workers in the initial steady state. For the time path of the output wedges, we assume a linear pattern between $\tau_{1998}^{y}$ and $\tau_{2012}^{y}$, such that $\tau_{t}^{y}=$ $\tau_{2012}^{y}-(2012-t) \kappa$ for $1998 \leq t \leq 2012$. For $t \geq 2013$, we assume $\tau_{t}^{y}=0$. We then calibrate $\tau_{2012}^{y}$ and $\kappa$ to best fit the trajectory of the private employment share between 1998 and 2011. This gives us $\kappa=0.027$ and $\tau_{2012}^{y}=0.01$.

\section{Main Results}

To assess the model's performance, we compare the simulated housing prices with both the annualized constant-quality housing price indices between 2006 and 2010 and the annual constant-quality national land price indices by Wu, Gyourko, and Deng (2012), updated with 2004-2012 data. ${ }^{45}$ Since land prices closely track housing prices (see Figure 1), we view land prices as a good proxy for housing prices for those years with missing housing price data. To illustrate the growth rate of housing prices relative to that of GDP, we also construct for the model and the data housing price-to-GDP ratios. Both housing prices and housing price-to-GDP ratios are normalized to 1 in 2004.

Figure 6 shows the main predictions of the model, together with their data counterparts. As Panel A shows, the simulated housing prices replicate the actual data fairly well until 2011, with an average growth rate of 19 percent between 2004 and 2011. The overprediction of housing prices in 2012 may be due to the fact that since 2010 the Chinese government has adopted several policies to control housing prices, from which our model is abstracted. Panel B shows that the simulated housing price-to-GDP ratio increases from 1 in 2004 to 1.77 in 2012, an average of 7.43 percent per year. Hence, our model can replicate the magnitude of the increase in housing prices relative to GDP reasonably well. We view this result as further support of our mechanism for housing price dynamics in China, since labor reallocation from F-firms to E-firms is key to delivering a sustained high return to E-firm capital, not only in absolute terms, but also relative to the growth rate of aggregate output.

\section{[Insert Figure 6 here]}

Panel $\mathrm{C}$ of Figure 6 shows that, by construction, our model closely matches the dynamics of the private employment share. Note that approaching 2012, the increase of the private employment share starts to slow down. This slowdown is caused by entre-

\footnotetext{
${ }^{45}$ The two most authoritative sources of housing price data are Wu, Gyourko, and Deng (2014) and Fang et al. (2015). Neither, however, has pre-2003 data. Other publicly available data for housing prices, such as the NBS average price index (total revenue of housing sales/floor area of housing sales), are severely biased downward (Wu, Deng, and Liu, 2014); hence, they are not reliable for our purposes. The year 2004 may be a good starting point for another reason: public auctions or bidding for land prices were non-existent before 2002 .
} 
preneurs slowing their accumulation of physical capital in anticipation of an increase in implicit output distortion.

Panel D of Figure 6 shows that the aggregate rate of return to capital is persistently high between 1998 and 2012. It starts to decline around 2008, which coincides with the turning point of the data. Two opposite effects in the calibrated economy drive these dynamics. On the one hand, an increase in the private employment share increases the average rate of return to capital, thanks to a higher E-firm rate of return to capital. On the other, the increase in implicit output distortion for E-firms during this period tends to reduce their net returns to capital.

Panel E of Figure 6 shows that the aggregate output growth in our model replicates China's GDP growth reasonably well: It remains around 10 percent between 1998 and 2012. Again, the observed hump shape of output growth rates is due to the aforementioned two opposite effects.

Panel F of Figure 6 plots the dynamics of aggregate Total Factor Productivity (TFP). Between 1998 and 2006, the average TFP growth rate is 6.13 percent. This is in line with the estimation of Brandt, Van Biesebroeck, and Zhang (2009), who estimate manufacturing sector TFP growth to be 6.1 to 7.7 percent during 1998-2006. Resource reallocation contributes 4.23 percent to annual TFP growth. Therefore, 69 percent of the TFP growth between 1998 and 2006 in our model is due to resource reallocation, which is broadly consistent with the findings of Brandt et al. (2009). A falling TFP growth rate in the second half of our sample period is due to an increase in the implicit output distortion toward E-firms, which, in turn, slows the pace of labor reallocation.

\section{Counterfactual Experiments}

We now conduct several counterfactual experiments to shed additional light on the structure of our model.

Heterogeneity. A standard representative-agent neoclassical growth model also features a transitional period of capital accumulation before reaching the steady state, along which the MPK declines gradually. Would a declining MPK generate housing price growth faster than GDP growth, everything else equal? The answer is no. To illustrate this, we exclude F-firms from our model so that the counterfactual economy is essentially neoclassical with only E-firms present and without the transition stage featuring "surplus" labor and resource reallocation-the focus of our model. In this counterfactual economy, the parameters $\chi$ and $\widehat{k}_{t}^{E}$ measure the aggregate, rather than E-firm-specific, productivity and capital stock, respectively. Therefore, we set $\widehat{k}_{1}^{E}$ to match the initial aggregate capital stock in the benchmark economy. We then recalibrate $\chi$ to target an initial 20 precent aggregate rate of return to capital. We keep all other parameters the same as in our benchmark economy. Figure 7 shows the simulated results in this counterfactual economy, together with their counterparts in the original model. Without firm heterogeneity, the private employment share always equals 100 percent (Panel C). Panel A shows that in this counterfactual economy, housing prices grow significantly slower than their benchmark counterparts. Two factors contribute to this result: first, in this counterfactual economy, the growth rate of housing prices equals the aggregate rate of 
return to capital; and second, the aggregate rate of return to capital falls over time along with capital accumulation (Panel D). In contrast, in our benchmark economy, the rate of housing price growth equals the rate of return to E-firm capital, and the AK feature of Efirms helps to sustain the high returns to capital during the transition. Accordingly, in this counterfactual economy, the housing price-to-GDP ratio is essentially flat (Panel B), despite a declining output growth rate (Panel E). Intuitively, without firm heterogeneity, the dynamics of aggregate output growth closely track the dynamics of the aggregate return to capital, which implies that housing prices grow at a rate similar to that of aggregate output. $^{46}$

[Insert Figure 7 here]

The Crowding-out Effects of Housing Bubbles. We now explore the normative implications of housing bubbles. To this end, we shut down entrepreneurs' access to the housing investment by setting $\phi_{t}^{E}=1$ for all $t$. Accordingly, without demand housing prices will always equal zero. All parameters remain the same as in the original calibration. Figure 8 plots the transition path for both the counterfactual and original economies. Panel A shows that without housing bubbles, the private employment share rises much faster. For example, by 2011, the private employment share is around 77 percent, which is 9 percent larger than in the benchmark. This finding implies that a housing bubble prolongs the economic transition. Panel B shows that with no housing bubble, aggregate output grows faster between 1998 and 2011, with an 11 percent average growth rate. Accordingly, the steady-state aggregate output is 6.23 percent larger than in the bubbly equilibrium. Panel $\mathrm{C}$ shows a similar pattern for the TFP growth rate. Between 1998 and 2011, TFP growth averages 6.05 percent per year, in contrast to 5.51 percent in our benchmark economy. Such a disparity suggests that housing bubbles exacerbate resource misallocation by crowding out productive investment, slowing labor reallocation from unproductive firms (F-firms) to productive firms (E-firms), thus resulting in permanently lower aggregate productivity and efficiency. Panel D suggests a significant welfare loss due to a housing bubble. Between 1998 and 2012, aggregate consumption would have been 6.35 percent higher without the housing bubble. Even at the steady state, aggregate consumption is 3.75 percent larger in the fundamental equilibrium. Intuitively, by crowding out productive capital investment, housing bubbles reduce the permanent incomes of future cohorts via both managers' compensation and the wage rate.

\section{[Insert Figure 8 here]}

The Housing Bubble Burst. Since a housing bubble is welfare reducing, it is tempting to conclude that it is welfare improving to burst it. Yet, this intuition is not entirely correct. To show this, we conduct an experiment with an unexpected bubble burst in year 2012 (the last period of our data sample) and compute the welfare effects on both

\footnotetext{
${ }^{46}$ When physical capital is not fully depreciated, the growth rate of total E-firm output will be somehow less than the aggregate or entrepreneurs' returns to capital because the growth rate of entrepreneurs' wealth is decreasing over time before the economy reaches the steady state.
} 
workers and entrepreneurs alive in that year. Implicitly, the welfare effects of such a counterfactual experiment could be used in a political-economy model under a majority voting scheme among existing cohorts regarding whether to burst the housing bubble. The results of the experiment are presented in Figure 9. Interestingly, all workers born before 1990 in our economy (which corresponds to cohorts in the data born in 1969 or earlier) do not experience welfare changes. This is because these cohorts of workers retire before the bubble bursts. Hence, their lifetime income, which is the present value of the wage rate, is unchanged. Workers born after 1990 experience welfare gains, because, with bursting housing bubbles, they enjoy an increase in the wage rate during their working periods once the economy enters the post-transition stage. The younger the workers are, the larger their welfare gains due to their ability to work for a longer period of time. Therefore, less than half of the workers strictly benefit from the bubble bursting.

[Insert Figure 9 here]

In contrast, all entrepreneurs alive in 2012 suffer welfare losses. Specifically, all old entrepreneurs (age 26 and older in our model) suffer a loss of housing wealth. For the young entrepreneurs, two offsetting welfare effects are present. On the one hand, the bubble burst increases the compensation of the young entrepreneurs for their remaining working periods as managers, thus increasing their lifetime income. On the other hand, the event decreases the rate of return to E-firm physical capital in the post-transition stage (which starts in 2019 in our model). Our quantitative results suggest that welfare losses outweigh the welfare gains for the young entrepreneurs alive in 2012.

To sum up, all entrepreneurs would suffer, while less than half of workers would strictly benefit from the bubble bursting. This is despite the fact that in the long run, all newborn entrepreneurs and workers would enjoy welfare gains. This welfare result provides a rationale for the Chinese government not to burst the housing bubble, even though doing so would be welfare improving in the long run.

\section{E. Further Discussions of Model Implications}

While the focus of our paper is on China, our model can shed light on housing bubbles in other emerging economies during their rapid-growth transition periods. The highlight of our theory is that economic transitions driven by massive resource reallocation must eventually end and that the associated high returns to capital are thus unsustainable in the long run. Such transition economies are prone to bubbles because such a dynamic path of returns to capital can induce even productive agents in the economy to seek alternative stores of value for their rapidly growing wealth. In financially underdeveloped economies with a limited supply of financial assets and tight capital controls, land or the housing market often becomes the natural target of speculative investment by all, including productive agents.

Indeed, other East Asian economies that experienced housing bubbles share transition patterns similar to China. Both South Korea and Taiwan in the 1980s experienced intersectoral labor reallocation from agriculture to manufacturing (or the service sector) and 
fast economic growth. ${ }^{47}$ Also, Vietnam has experienced a transition stage similar to that of China. Moreover, during their respective bubble episodes, these economies featured financial underdevelopment similar to China's. For both Korea and Taiwan, between 1985 and 1989, bank deposits represented the major share of household financial assets (49.8 percent for Korea and 59.7 percent for Taiwan). ${ }^{48}$ Similarly, in Vietnam, the banking sector dominated the financial system, with its assets amounting to about 183 percent of GDP and 92 percent of all financial institution assets in 2011. Therefore, a brief analysis of these other housing booms serves as a useful examination of the relevance of our theory for other emerging countries.

In South Korea, land/housing prices almost tripled during 1985-1991, with a 21.5 percent average annual growth rate. ${ }^{49}$ This growth rate is in contrast to the 12.5 percent average real GDP growth rate during the same period. Interestingly, this housing boom coincided with important structural changes in the Korean economy. In the 1980s, Korea experienced a massive reallocation of labor from agriculture to other sectors. The share of agricultural employment dropped by 20 percent between 1980 and 1992, compared with a mere 6 percent drop between 1992 and 2007 (Lee, 2010). Labor costs had been increasing significantly since the mid-1980s, reflecting a pending shortage of labor (Smith, 2000, Figure 3.3). While the increase slowed by the early 1990s, the real average monthly earnings in manufacturing still grew an average 7.8 percent per year between 1992 and 1996, while productivity growth lagged. This increase in labor costs, which led to a rapid increase in relative export prices, increasingly undermined Korean firms' competitiveness during this period (Smith, 2000, Figure 3.2). Such a pattern was consistent with the dynamics of the rate of return to capital for Korea, which was very high and increased for most of the 1980s before it started to fall in the late 1980s (Panel A of Figure 10). ${ }^{50}$

\section{[Insert Figure 10 here]}

Similar to South Korea's experiences, the housing boom in Taiwan occurred during a time of massive labor reallocation and fast economic growth. According to Koo and Park (1994), Taiwan witnessed a sharp increase in land prices in the second half of the

\footnotetext{
${ }^{47}$ SSZ (2011) emphasize resource reallocation to financially constrained private firms within the manufacturing sector as a key reason for the coexistence of the acceleration of productivity growth and foreign surplus in Korea and Taiwan in the 1980s. We view the intersectoral labor reallocation as essential for the housing booms experienced in these two countries during the 1980s.

${ }^{48}$ In Korea, moreover, the government had continued to control and constrain capital inflow until 1992. Accordingly, foreign liabiliy was only 3.7 percent of the total liability of nationwide commerical banks in 1990 (Park, 1994). Similarly, in Taiwan, domestic banks obtained a majority of their funds from domestic deposits (e.g., about 70 percent in 1990). In addition, the government of Taiwan kept the operations of foreign banks under strict control to protect domestic banks and maintain financial stability (Shea, 1994).

${ }^{49}$ See Koo and Park (1994, Table 3.9) and Kim and Lee (2000). Also, according to these two studies, between 1980 and 1985, land prices increased by only 60 percent. After 1992, both land and housing prices leveled off until the 1997-98 financial crisis.

${ }^{50}$ Nugent and Yhee (2002, Table 6) obtained a similar finding for the dynamics of capital productivity, especially for small and medium-sized enterprises. Specifically, capital productivity, measured by the ratio of gross value added to total assets, is more than 35 percent for small and medium-sized enterprises and more than 24 percent for large enterprises during 1985-1991. This is in contrast to a declining pattern of capital productivity for both types of firms between 1992 and 1997.
} 
1980s. Accordingly, average housing prices in the Taipei area more than quadrupled from late 1986 to early 1990 (implying a more than 40 percent annual growth rate in housing price during this period). ${ }^{51}$ During the same period, real GDP growth averaged 9.1 percent annually. At the micro level, Taiwan experienced fast reallocation of labor from agriculture to the manufacturing and service sectors starting in the 1970s. The share of agricultural employment decreased from 25 percent in 1978 to 13 percent in 1989. A labor shortage had gradually become apparent in the manufacturing sector starting the late 1970s and even more so after the mid-1980s. Labor costs rose as a result of this labor shortage. The average monthly real wage, which increased by 6.5 percent per year during 1981-1986, increased by 11.4 percent per year between 1986 and $1990 .^{52}$ Accordingly, Panel B of Figure 11 shows that Taiwan's rate of return to capital peaked in 1986-1987 and declined thereafter.

Similar to China, Vietnam has witnessed a massive labor reallocation from SOE toward the private sector in the past decade following a series of reforms (e.g., the establishment of the 2000 Enterprise Law). For example, within the manufacturing sector, the share of workers employed by SOE has declined from 30.5 percent in 1999 to 8.9 percent in 2009, while the share of workers employed by foreign-owned firms has increased from 5.2 percent to 22.4 percent. ${ }^{53}$ Associated with Vietnam's structural change is its fast economic growth. According to the International Monetary Fund, Vietnam's average GDP growth was 7.2 percent between 2000 and 2010—one of the fastest-growing economies in the world during this period.

Along with its economic transition, Vietnam's real estate market has undergone remarkable changes in recent years and boomed between 2007 and 2010. In 2003, the Vietnamese government enacted the Law on Land. This law cast the most significant reform of legal property rights in Vietnam's history and paved the way for market-driven real estate prices in Vietnam. For example, housing prices increased by 200 percent between 2007 and the first half of 2008 and medium- to high-quality condominiums became one of the hottest asset markets, second only to Vietnam's booming stock market. The incredible rise in housing prices, nonetheless, was believed to be the result of significant speculation rather than by changes in fundamentals. Since the beginning of 2011, the real estate market in Vietnam has suffered huge losses in market value. Housing prices have dropped 40 percent on average since then.

Therefore, despite important cultural and institutional differences, these three emerging economies had development paths with features similar to China's recent experience. Specifically, housing prices in all three economies grew faster than their GDPs despite high returns to capital during their respective economic transitions. Moreover, for both Korea and Taiwan, the completion of the transition process eventually leads to rising labor costs and the slowdown of housing price growth. These features are consistent with

\footnotetext{
${ }^{51}$ See Chen (2001, Table 1) for data on the real housing price growth rate for Taipei during the late 1980s, and Tsai and Peng (2011) for evidence on the housing market boom for other major cities in Taiwan during this period.

${ }^{52}$ Similar to Korea, Taiwan also experienced a sharp increase in relative export prices in the second half of the 1980 s (Smith 2000, Figure 3.2).

${ }^{53}$ See McCaig and Pavcnik (2013, Table 5). According to them, another important structural change during this period is the acceleration of the reallocation of labor from the agricultural sector to the manufacturing and service sectors.
} 
the predictions of our theory.

\section{Conclusion}

This paper provides a framework to explain the coexistence of three paradoxical features of the housing boom in China-housing price growth persistently higher than income growth, high returns to capital, and high vacancy rates across major Chinese cities. Our theory suggests that China's unprecedented income growth is not the full story behind the housing boom. The decade-long housing boom contains a rational bubble arising naturally from China's economic transition, which features labor reallocation from the traditional low-productivity sector to the newly emerging high-productivity sector. Such labor reallocation sustains a very high rate of return to capital in the emerging sector. Yet, these high returns to capital will eventually end when surplus labor is depleted. Hence, rational expectations of strong demand for alternative stores of value in the future can induce even the most productive current agents to speculate in the housing market, creating a self-fulfilling housing bubble that can grow much faster than aggregate income despite high returns to capital. The model's predictions are thus consistent (qualitatively and quantitatively) not only with China's broad pattern of economic growth but also with the three paradoxical features of the housing boom. We also show that such a growing housing bubble can crowd out productive capital investment, thus prolonging the economic transition and reducing social welfare.

A number of simplifying assumptions make our model tractable. For example, in our model, housing does not provide utility services and workers do not participate in the housing market. Although we have argued that such omissions should not affect our main results, a richer model with both workers and entrepreneurs speculating in the housing market would enrich the welfare implications of a growing housing bubble. For example, a growing housing bubble distorts homeowner life-cycle consumption patterns under borrowing constraints by forcing people to oversave when young to enter the housing market. Furthermore, rapidly rising housing prices tend to worsen wealth inequalities across income classes, as housing price growth is driven largely by the high- and uppermiddle-income classes that have enjoyed the most rapid income growth during China's economic development. In contrast, under borrowing constraints, more and more lowincome households are excluded from the housing market because their income growth lags housing price growth. Moreover, our model abstracts from several institutional details of China's housing and land markets (e.g., a local government's heavy reliance on revenue from land sales), which we believe might also contribute to the size (but not the growth rate) of China's housing bubble. These are all important issues for our future research.

Despite its simplicity, a calibrated version of our model quantitatively matches the growth dynamics of housing prices and other salient features of China's recent experience reasonably well. We therefore view our model as a useful starting point for studying the macroeconomic implications of the growing housing bubble in China. For example, a growing housing bubble reduces the private sector's incentive to innovate. Because of the relatively low risk, low entry costs, and high profits in housing investment, the 
housing bubble has enticed many productive and high-tech firms in China to reallocate resources from research and development to the real estate market. In an economy in transition from a labor-intensive economy to a capital-intensive economy, such resource misallocation can be very costly: It may substantially prolong China's economic transition and reduce China's TFP growth, especially when its population is aging fast and labor costs are rapidly rising. We plan to empirically validate and quantify such resource misallocation within our framework in future works.

\section{REFERENCES}

[1] Abel, Andrew B., N. Gregory Mankiw, Lawrence H. Summers, and Richard J. Zeckhauser (1989), "Assessing Dynamic Efficiency: Theory and Evidence," Review of Economic Studies, 56, 1-20.

[2] Adrian, Tobias, Erkko Etula, and Tyler Muir (2014), "Financial Intermediaries and the Cross-Section of Asset Returns," Journal of Finance, 69(6), 2557-2596.

[3] Bai, Chong-en, Chang-Tai Hsieh, and Yingyi Qian (2006), "The Return to Capital in China," Brookings Papers on Economic Activity, 2, 61-88.

[4] Bai, Chong-en, David D. Li, Zhigang Tao, and Yijiang Wang (2000), "A MultiTask Theory of the State Enterprise Reform," Journal of Comparative Economics, 28, 716-738.

[5] Bayoumi, Tamim and Franziska Ohnsorge (2013), "Do Inflows or Outflows Dominate? Global Implications of Capital Account Liberalization in China," IMF Working Paper, No. 13/189.

[6] Brandt, Loren, Johannes Van Biesebroeck, and Yifan Zhang (2009) "Creative Accounting or Creative Destruction? Firm-Level Productivity Growth in Chinese Manufacturing," NBER Working Paper No. 15152.

[7] Buera, Francisco J. and Yongseok Shin (2013), "Financial Frictions and the Persistence of History: A Quantitative Exploration," Journal of Political Economy, 121, 221-272.

[8] Buera, Francisco J., Joseph P. Kaboski and Yongseok Shin (2011), "Finance and Development: A Tale of Two Sectors," American Economic Review, 101(5), 19642002.

[9] Burnside, Craig, Martin Eichenbaum and Sergio Rebelo (2013), "Understanding Booms and Busts in Housing Markets," Working Paper, Northwestern University.

[10] Caballero, Ricardo J. and Arvind Krishnamurthy (2006), "Bubbles and Capital Flow Volatility: Causes and Risk Management," Journal of Monetary Economics, 53(1), 35-53. 
[11] Chen, Nan-Kuang (2001), "Asset Price Fluctuations in Taiwan: Evidence from Stock and Real Estate Prices 1973 to 1992," Journal of Asian Economics, 12, 215232.

[12] Chen, Ting, Laura Xiaolei Liu, and Li-An Zhou (2013), "The Crowding-out Effects of Real Estate Shocks_-Evidence from China," Working Paper, Guanghua School of Management, Beijing University.

[13] China Household Finance Survey (2014), "Urban Housing Vacancy Rate and the Trend of Housing Market Development," Unpublished Manuscript, Southwestern University of Finance and Economics, China.

[14] Curtis, Chadwick C., Steven Lugauer, and Nelson C. Mark (2015), "Demographic Patterns and Household Saving in China," American Economic Journal, Macroeconomics, 7(2) 58-94.

[15] Fang, Hanming, Quanlin Gu, Wei Xiong and Li-An Zhou (2015), "Demystifying the Chinese Housing Boom," forthcoming, NBER Macroeconomic Annual, 2015. Edited by Martin Eichenbaum and Jonathan Parker, Chicago, IL: University of Chicago Press.

[16] Farhi, Emmanuel and Jean Tirole (2012), "Bubbly Liquidity," Review of Economic Studies, 79(2), 678-709.

[17] Galí, Jordi (2014), "Monetary Policy and Rational Asset Price Bubbles," American Economic Review, 104(3): 721-52.

[18] Garriga, Carlos, Yang Tang and Ping Wang (2014), "Rural-Urban Migration, Structural Transformation, and Housing Markets in China," Federal Reserve Bank of St. Louis Working Paper 2014-028A.

[19] Ge, Suqin. and Dennis T. Yang (2014), “Changes in China's Wage Structure," Journal of European Economic Association, 12(2), 300-336.

[20] Giglio, Stefano and Tiago Severo (2012), "Intangible Capital, Relative Asset Shortages and Bubbles," Journal of Monetary Economics, 59(3), 303-317.

[21] Grossman, Gene M. and Noriyuki Yanagawa (1993), "Asset Bubbles and Endogenous Growth," Journal of Monetary Economics, 31, 3-19.

[22] Guner, Nezih, Gustavo Ventura, and Yi Xu (2008), "Macroeconomic Implications of Size Dependent Policies," Review of Economic Dynamics, 11(4), 721-744.

[23] Jeong, Hyeok and Robert M. Townsend (2007), "Source of TFP Growth: Occupational Choice and Financial Deepening," Economic Theory 32(1), 197-221.

[24] Kim, Kyung-Hwan and Hahn Shik Lee (2000), "Real Estate Price Bubble and Price Forecasts in Korea," unpublished manuscript. 
[25] King, Ian and Don Ferguson (1993), "Dynamic Inefficiency, Endogenous Growth, and Ponzi Games," Journal of Monetary Economics, 32(1), 79-104.

[26] Kocherlakota, Narayana (2009), "Bursting Bubbles: Consequences and Cures," Unpublished manuscript, University of Minnesota.

[27] Koo, Bon Ho and Won-Am Park (1994), "Perspectives on Korea's External Adjustment: Comparison with Japan and Taiwan," in Macroeconomic Linkage: Savings, Exchange Rates and Capital Flows. Edited by Takatoshi Ito and Anne O. Krueger, Chicago, IL: University of Chicago Press.

[28] Lee, Sophia Seung-yoon (2010), "The Shift of Labour Market Risks in Deindustrializing Asian Economies: Taiwan, Japan and the Republic of Korea." In New Welfare States in East Asia: Global Challenges and Restructuring." Edited by Gyu-Jin Hwang. Sydney: Edward Elgar.

[29] Li, Xu, Xiang Shao, and Zhigang Tao (2015), "Hollowing Out of the Real Economy: Evidence from China's Listed Firms," Working Paper, University of Hong Kong.

[30] Martin, Alberto and Jaume Ventura (2012), "Economic Growth with Bubbles," American Economic Review, 102(6), 3033-3058.

[31] McCaig, Brian and Nina Pavcnik (2013), "Moving out of Agriculture: Structural Change in Vietnam,” NBER Working Paper, No. 19616.

[32] Miao, Jianjun and Pengfei Wang (2013), "Bubbles and Credit Constraints," Working Paper, Boston University.

[33] Miao, Jianjun, Pengfei Wang and Jing Zhou (2016), "Housing Bubbles and Policy Analysis," forthcoming, Journal of Monetary Economics.

[34] Midrigan, Virgiliu and Daniel Yi Xu (2014), "Finance and Misallocation: Evidence from Plant-Level Data," American Economic Review, 104(2), 422-458.

[35] Moll, Benjamin (2014), "Productivity Losses from Financial Frictions: Can Selffinancing Undo Capital Misallocation?", American Economic Review 104 (10), 3186-3221.

[36] Nugent, Jeffery B. and Seung-Jae Yhee (2002), "Small and Medium Enterprises in Korea: Achievements, Constraints and Policy Issues," Small Business Economics, 18(1-3), 85-119.

[37] Park, Yung Chul (1994), "Korea: Development and Structural Change of the Financial System," in The Financial Development of Japan, Korea and Taiwan, Edited by Hugh T. Patrick and Yung Chul Park, Oxford, UK: Oxford University Press.

[38] Restuccia, Diego and Richard Rogerson (2008), "Policy Distortions and Aggregate Productivity with Heterogeneous Plants," Review of Economic Dynamics, 11(4), 707-720. 
[39] Shea, Jia-Dong (1994), "Taiwan: Development and Structural Change of the Financial System." in The Financial Developement of Japan, Korea, and Taiwan. Edited by Hugh T. Patrick and Yung Chul Park, Oxford, UK: Oxford University Press.

[40] Smith, Heather (2000), Industry Policy in Taiwan and Korea in the 1980s, Northampton, Massachussets: Edward Elgar.

[41] Song, Zheng, Kjetil Storesletten, and Fabrizio Zilibotti (2011), "Growing Like China," American Economic Review, 101, 196-233.

[42] Tirole, Jean (1985), "Asset Bubbles and Overlapping Generations," Econometrica, 53(6), 1499-1528.

[43] Ventura, Jaume (2012), "Bubbles and Capital Flows," Journal of Economic Theory, 147(2), 738-758.

[44] Wei, Shang-Jin, Xiaobo Zhang, and Yin Liu (2012),"Status Competition and Housing Prices," NBER Working Paper No. 18000.

[45] Wu, J., Y. Deng, and H. Liu (2014), "House Price Index Construction in the Nascent Housing Market: The Case of China," Journal of Real Estate Finance and Economics, 48(3), 522-545.

[46] Wu, Jing, Joseph Gyourko, and Yongheng Deng (2012), "Evaluating Conditions in Major Chinese Housing Markets," Regional Science and Urban Economics, 42 (3): 531-543.

[47] Wu, Jing, Gyourko, Joseph and Yongheng Deng (2015), "Real Estate Collateral Value and Investment: The Case of China," Journal of Urban Economics, 86, 4353.

[48] Yi, Gang and Wang Song (2008), "The Evolution of China's Financial Assets Structure: 1991-2007,' Economic Research Journal (Jin Ji Yan Jiu), (in Chinese), 8, 415. 
Tables and Figures

Table 1. Excess Housing Price Growth and Capital Returns

\begin{tabular}{cccc}
\hline \hline Variable & $(1)$ & $(2)$ & $(3)$ \\
\hline Private Capital Returns & $0.8153^{* * *}$ & & $0.7101^{* * *}$ \\
SOE Capital Returns & $(0.1725)$ & $0.7573^{* * *}$ & $0.5091^{* *}$ \\
Observations & & $(0.2676)$ & $(0.2124)$ \\
$R^{2}$ & 139 & 139 & 139 \\
& 0.2349 & 0.1111 & 0.2819 \\
\hline
\end{tabular}

Note: Numbers in parentheses are standard errors. This table reports the results from our fixed-effects panel regression with excess housing price growth as the dependent variable and private and/or SOE capital returns as the independent variables. The estimation uses the robust or sandwich estimator of variance. The data are a balanced panel covering 35 major cities in China between 2006:Q1 and 2010:Q4.

Source: The data for the housing prices are from Wu, Deng, and Liu (2014); for disposable income growth are from NBSC statistical communiqués (various issues); and for capital returns are from the various issues of China Statistical Yearbook (CSY).

$* * *$ Significant at the 1 percent level. ** Significant at the 5 percent level.

Table 2. Summary Statistics for Firms with Investment Property

\begin{tabular}{ccccc}
\hline Year & $\begin{array}{c}\text { Total Number } \\
\text { of Firms }\end{array}$ & $\begin{array}{c}\text { Firms } \\
\text { with IP }\end{array}$ & $\begin{array}{c}\text { Share of Firms with IP } \\
\text { (in percent) }\end{array}$ & $\begin{array}{c}\text { Average IP/(IP+PPE) } \\
\text { (in percent) }\end{array}$ \\
\hline 2007 & 1373 & 609 & 44.36 & 16.03 \\
2008 & 1489 & 662 & 44.46 & 15.64 \\
2009 & 1534 & 699 & 45.57 & 15.54 \\
2010 & 1681 & 732 & 43.55 & 15.57 \\
2011 & 2027 & 858 & 42.33 & 14.46 \\
2012 & 2254 & 872 & 38.69 & 13.86 \\
2013 & 2249 & 926 & 41.17 & 13.35 \\
\hline \hline
\end{tabular}

Note: IP denotes investment property. PPE denotes property, plants and equipment. This table provides the summary statistics for non-real estate publicly-listed firms holding property assets for investment purposes. We restrict our sample to firms that have been traded for at least two years on the China A-share stock market over the period 2007-2013. We exclude firms in the real estate and construction sectors.

Source: The firm-level data are from CSMAR and the authors' calculations. 
Table 3. Returns to Capital and Ownership Structure

\begin{tabular}{cccc}
\hline \hline & $(1)$ & $(2)$ & $(3)$ \\
\hline Variable & Measure 1 & Measure 2 & Measure 3 \\
\hline State ownership & $-1.02734^{* * *}$ & $-0.13056^{*}$ & $-0.49989^{* * *}$ \\
& $(-9.32)$ & $(-1.64)$ & $(-8.98)$ \\
Observations & 10957 & 10957 & 10957 \\
$R^{2}$ & 0.2573 & 0.2521 & 0.2547 \\
\hline \hline
\end{tabular}

Note: This table reports the estimated coefficient in a regression of returns to capital against three measures of state ownership and four one-digit industry dummies. Measure 1 is the state-owned stock share; measures 2 and 3 are stateownership dummies with the value 1 if a firm's state-owned stock share exceeds $50 \%$ and $25 \%$, respectively.

*** Significant at the 1 percent level. ** Significant at the 5 percent level. * Significant at the 10 percent level.

Table 4. Correlation between Housing Price Growth and Fixed Investment Growth

\begin{tabular}{c|cc}
\hline \hline \multicolumn{2}{|c}{ Nationwide } \\
\hline Time & Real Estate Investment & Other Investment \\
\hline Current & $0.5255^{* *}$ & $-0.3212^{* *}$ \\
$t-1$ & $0.4765^{* *}$ & $-0.4046^{* *}$ \\
$t-2$ & $0.4115^{* *}$ & $-0.4499^{* *}$ \\
$t-3$ & $0.3320^{* *}$ & $-0.5025^{* *}$ \\
$t-4$ & $0.2710^{* *}$ & $-0.5467^{* *}$ \\
$t-5$ & 0.2025 & $-0.5438^{* *}$ \\
$t-6$ & 0.1288 & $-0.5171^{* *}$ \\
\hline
\end{tabular}

Source: The aggregate monthly housing price data are for January 2006 to December 2011 and from Wu, Deng, and Liu (2014). The corresponding monthly investment data are from the CSY (various issues). To remove seasonality, the growth rates for housing prices and investment are year-over-year growth rate at monthly frequency.

** Significant at the 5 percent level. 


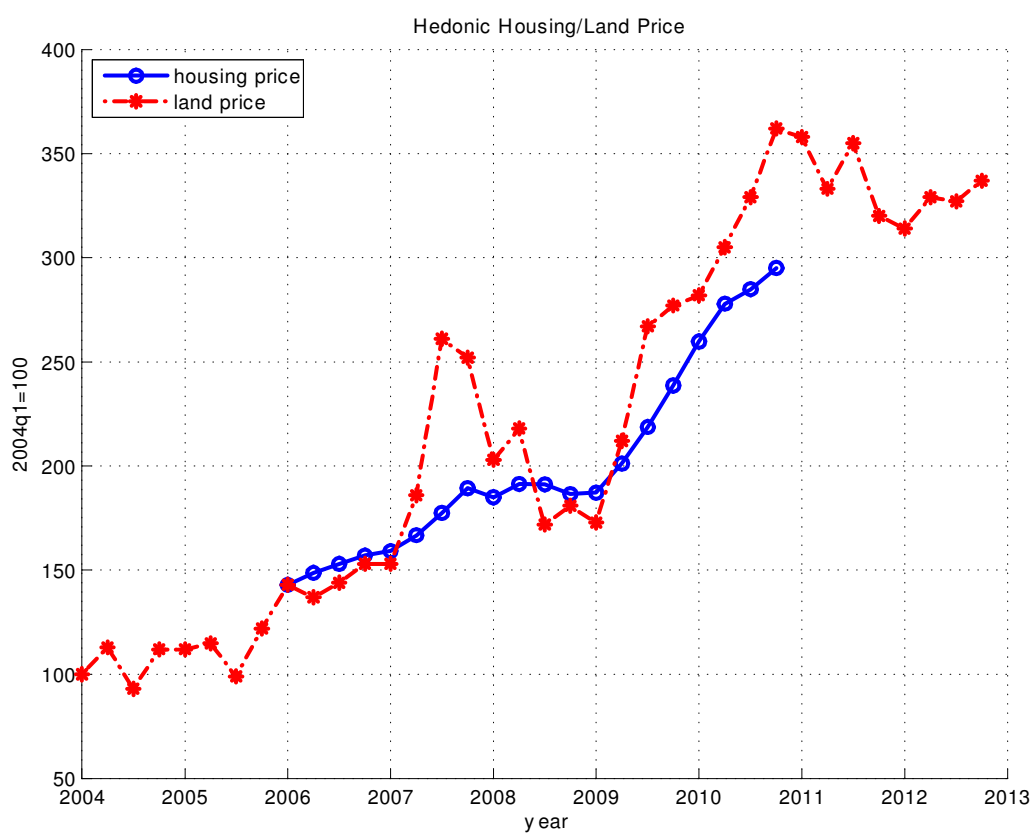

Figure 1. Housing and Land Prices in China

Source: The hedonic housing price data are from Wu, Deng, and Liu (2014), and the hedonic land price data are from Wu, Gyourko, and Deng (2012, downloadable from

http://real.wharton.upenn.edu/ gyourko/chineselandpriceindex.html.) 


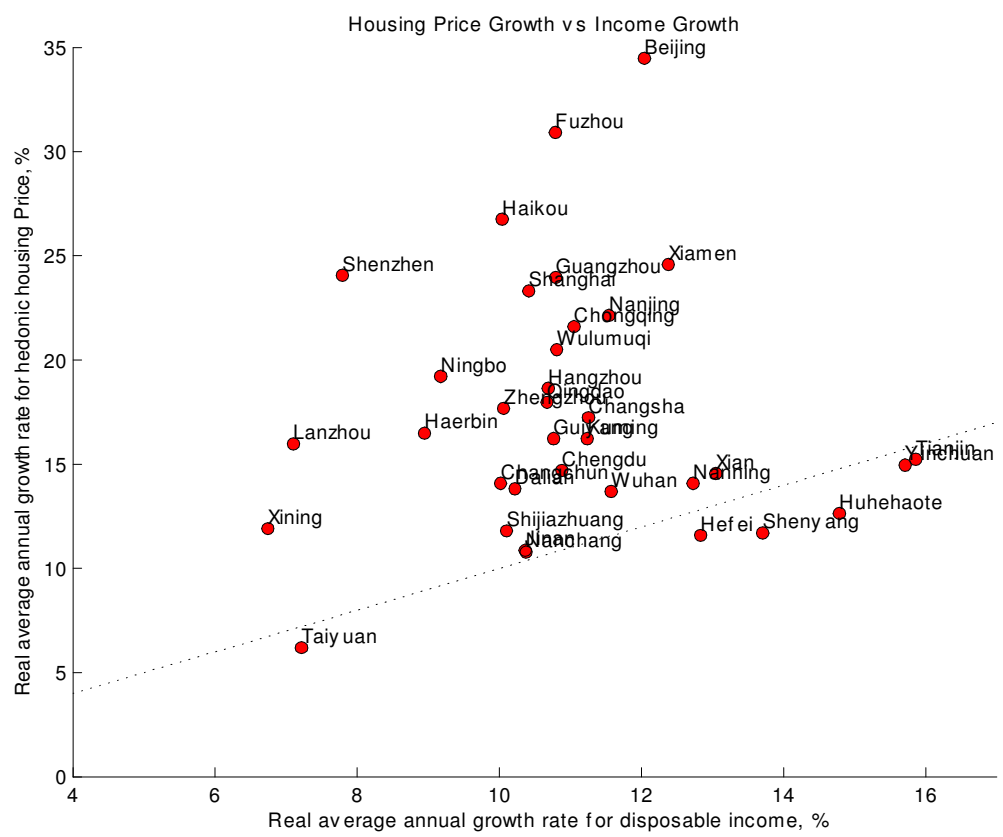

Figure 2. Growth Rate of Housing Prices and Aggregate Income across Thirty-five Major Cities in China (2006-2010)

Source: The hedonic housing price data are from Wu, Deng, and Liu (2014). The growth of disposable income is computed by the authors based on the growth rate of real disposable income and the growth rate of the urban-residing population from NBSC statistics communiqués (various issues). 

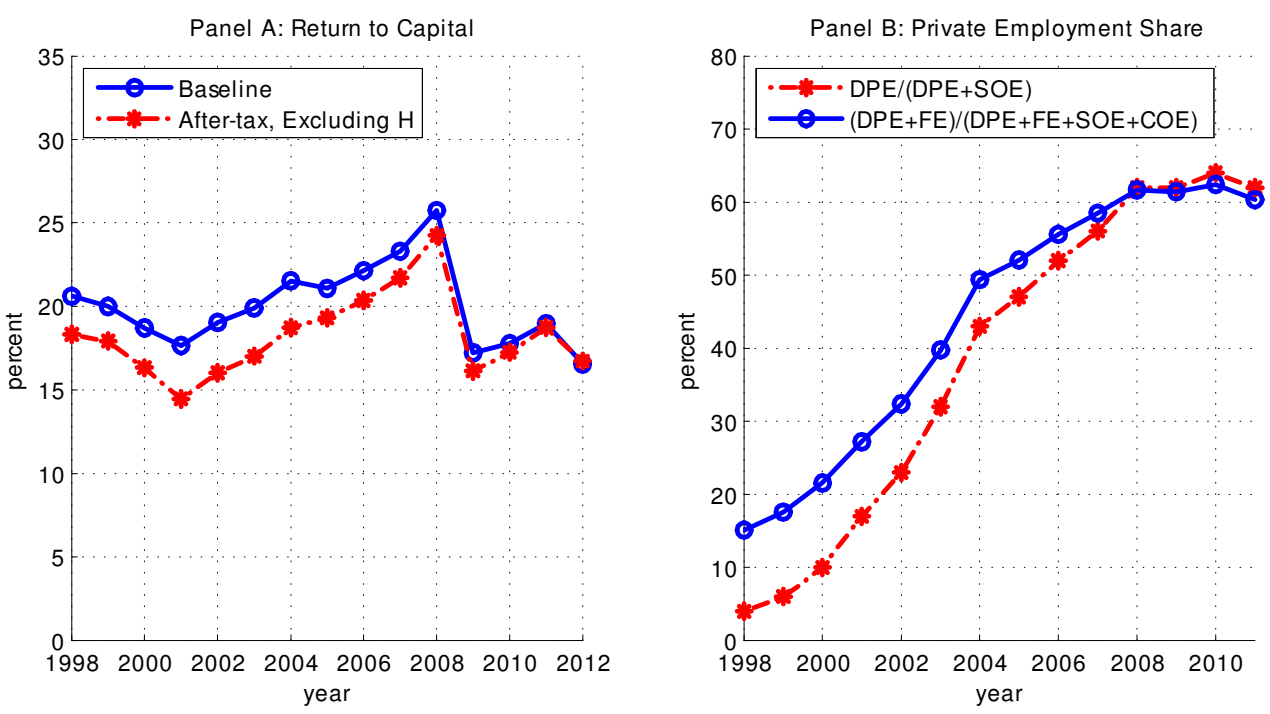

Figure 3. Returns to Capital and Labor Reallocation

Note: DPE, domestic private enterprises; FE, foreign enterprises; SOE; state-owned enterprises; COE, collectively owned enterprises.

Source: In Panel A, the rate of return to capital is computed by the authors using the approach of Bai, Hsieh, and Qian (2006) and data from the CSY (various issues). The line with circles is the gross rate of return to capital, and the dash-dotted line is the after-tax return to capital excluding urban residential housing. In Panel B, the private employment shares are computed by the authors using data from the CSY (various issues). 


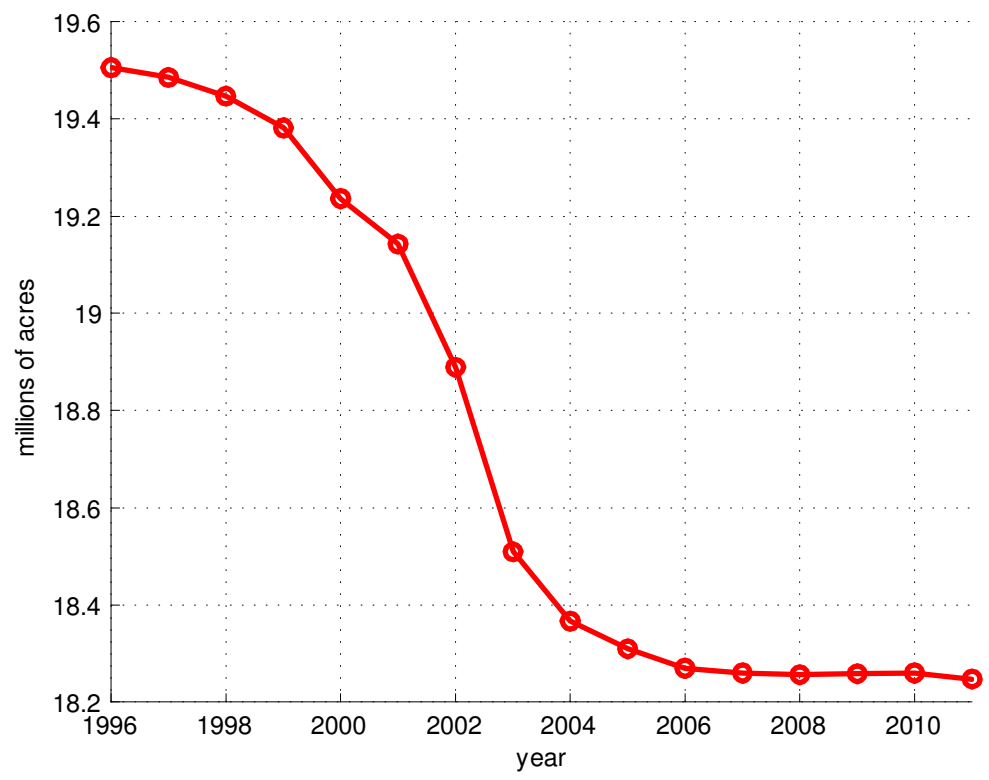

Figure 4. Total Amount of Arable Land

Source: $C S Y$ (various issues). 


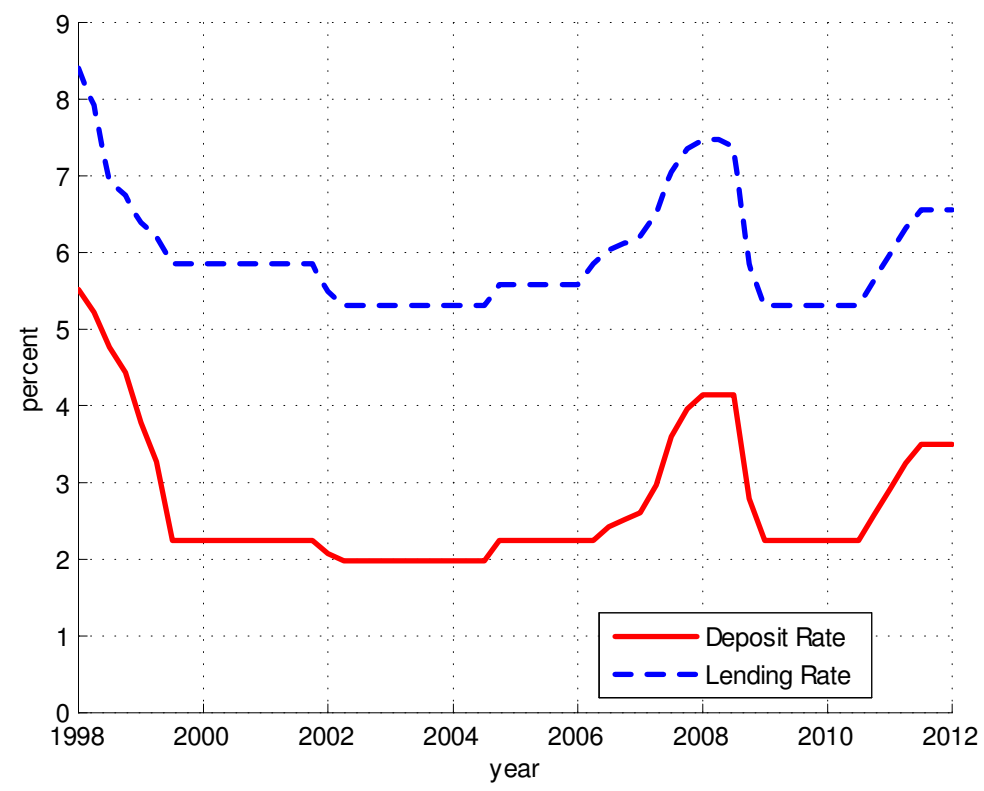

Figure 5. China's One-Year Benchmark Nominal Interest Rates Source: CEIC database. 

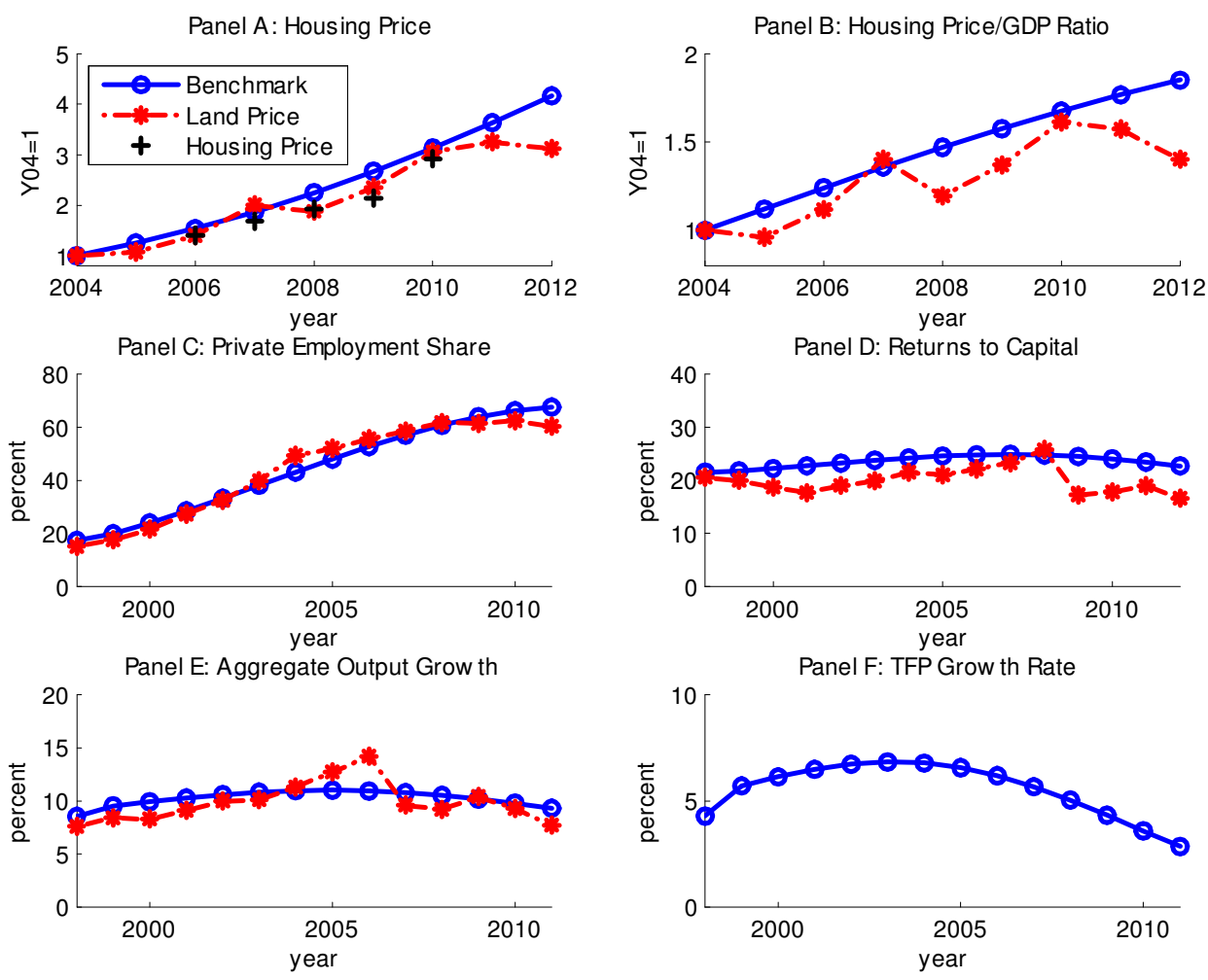

Figure 6. Transition in the Multi-period Calibrated Economy

Note: This figure shows the evolution of key variables during and after transition of the calibrated economy. The solid and dash-dotted lines refer to the simulated results from the model and the data, respectively. In Panel A, the plus sign refers to annualized housing price data from Wu, Deng, and Liu (2014), whereas the dash-dotted line refers to annual land price data from Wu, Gyourko, and Deng (2012). Both the simulated housing price data and actual land price data are normalized to 1 in 2004. The housing price data in 2006 are normalized to equal the normalized actual land price data in 2006. 

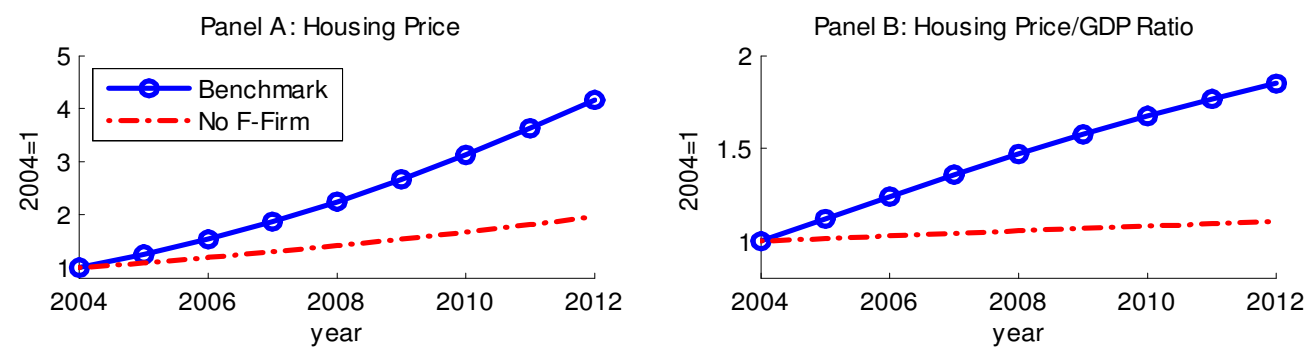

Panel C: Private Employment Share

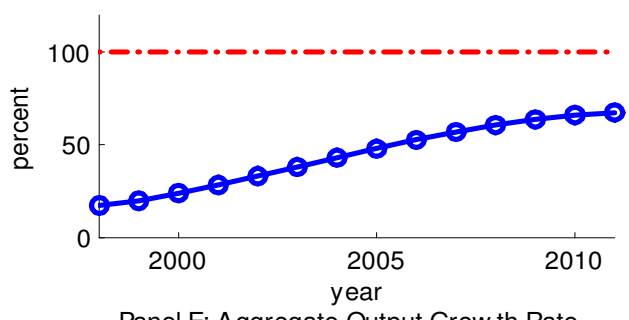

Panel D: Returns to Capital
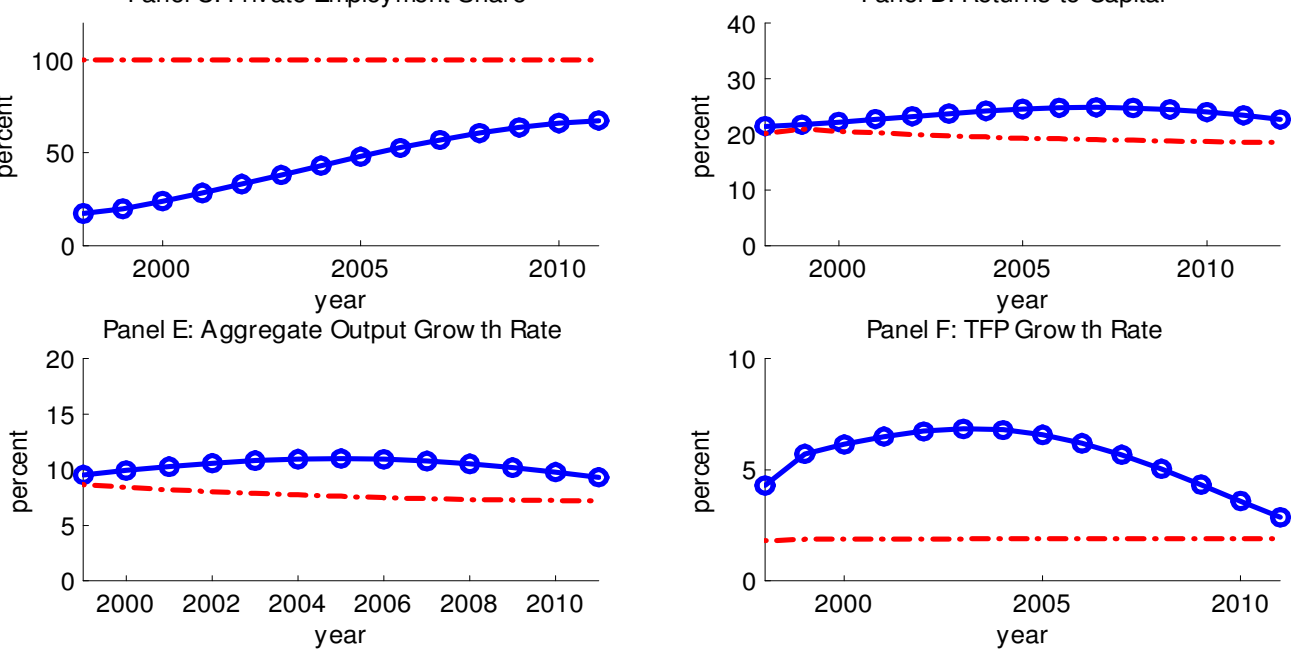

Figure 7. The Role of Firm Heterogeneity in the Calibrated Economy

Note: The figure shows the evolution of key variables in the calibrated economy (solid line) and the counterfactual economy in which there are no F-firms (dash-dotted line). 

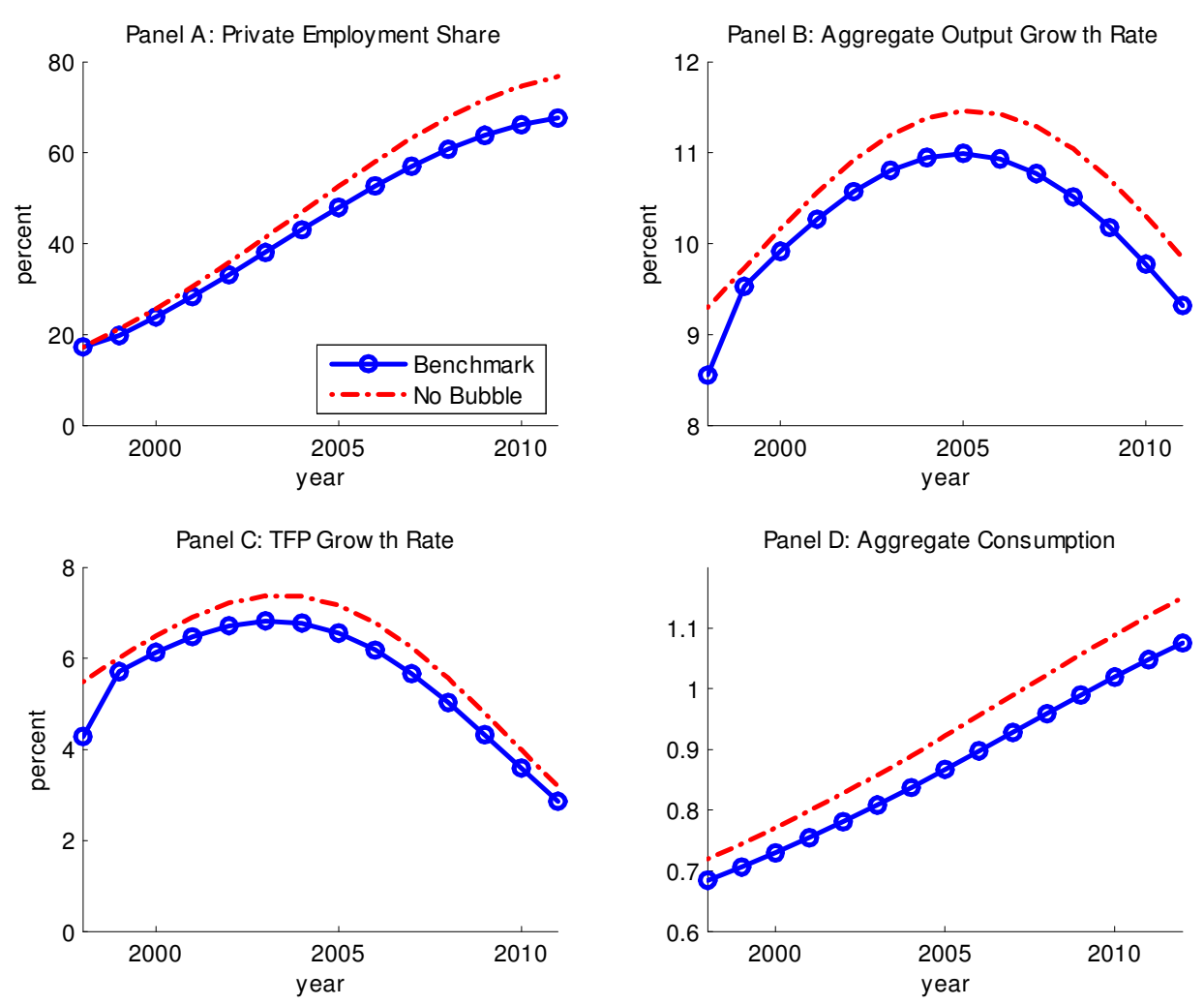

Figure 8. The Welfare Effects of Housing Bubbles in the Calibrated Economy

Note: The figure shows the evolution of key variables in the calibrated economy (solid line) and the counterfactual economy in which there are no housing bubbles (dash-dotted line). 


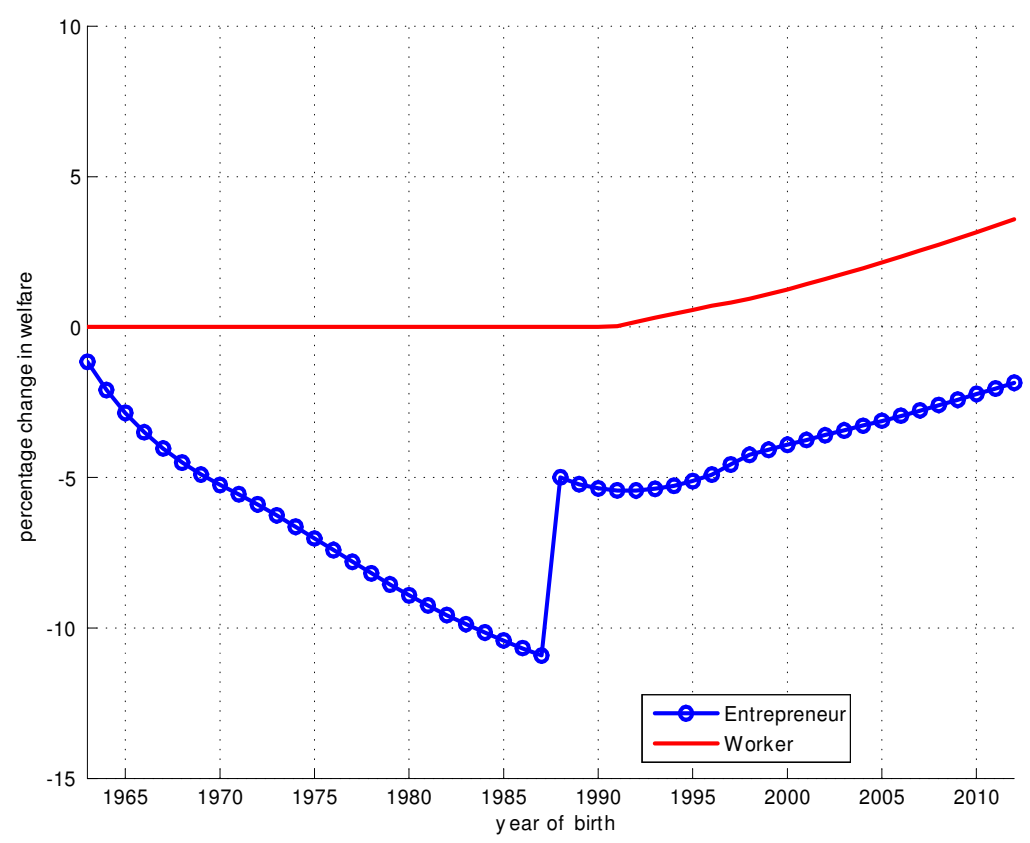

Figure 9. Welfare Effects of a Housing Bubble Bursting in 2012

Note: This figure shows the welfare effects of an unexpected burst of a housing bubble in 2012 for all cohorts alive at the time of the burst. 

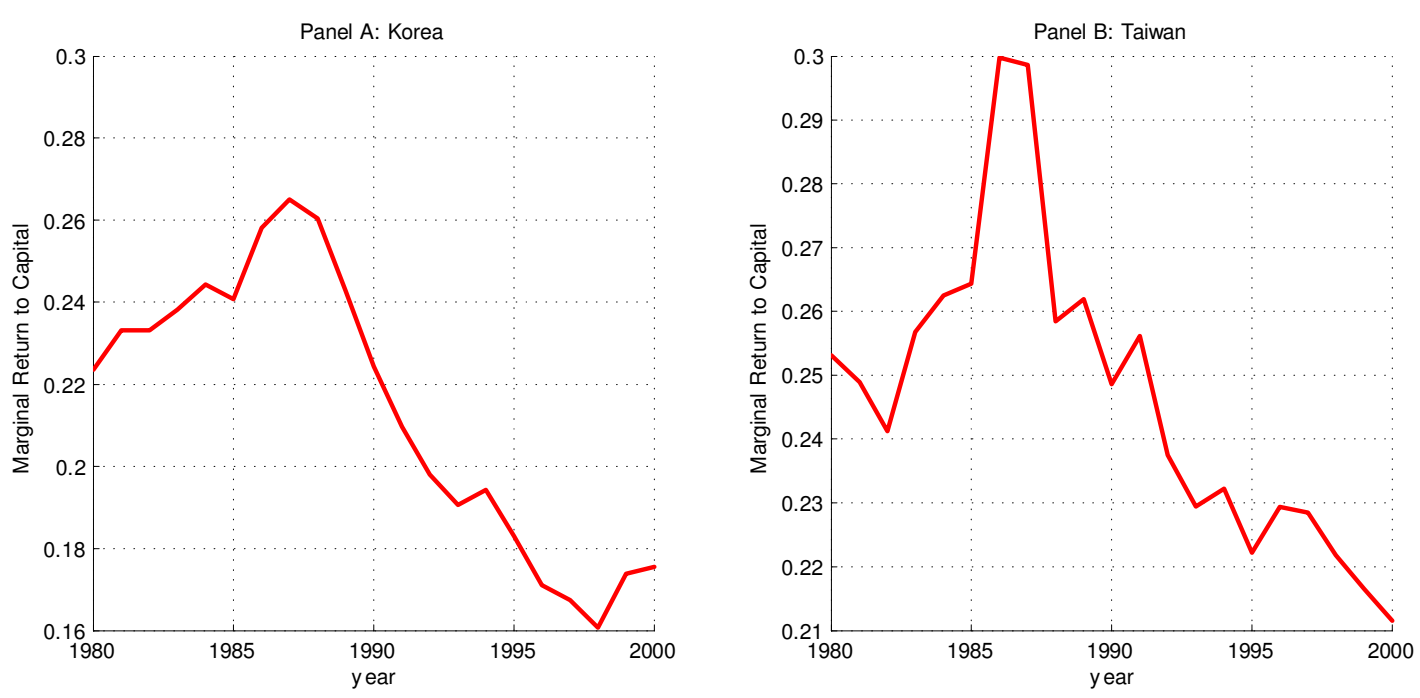

Figure 10: Rates of Return to Capital in Korea and Taiwan

Note: The figures show the rate of return to capital for Korea and Taiwan during housing bubbles in these two countries.

Source: The rates of return to capital are computed by the authors as $(1-$ labor share $t) \times Y_{t} / K_{t}-\delta_{t}$. GDP, capital stock, and capital depreciation rate data are from the Penn World Table (8.0). $Y_{t}$ is output-side real GDP at current PPPs in millions 2005US\$, $K_{t}$ is capital stock at current PPPs in millions 2005US\$, and $\delta_{t}$ is average depreciation rate of the capital stock. We convert $Y_{t}$ and $K_{t}$ into the local currency when computing the rate of return to capital for individual countries. 